University of Wollongong

Research Online

Faculty of Engineering and Information

Faculty of Engineering and Information

Sciences - Papers: Part B

Sciences

2019

Performance evaluation of intermittently CFRP wrapped square and circularised square reinforced concrete columns under different loading conditions

Anh Duc Mai

University of Wollongong, mad766@uowmail.edu.au

M Neaz Sheikh

University of Wollongong, msheikh@uow.edu.au

Muhammad N. S Hadi

University of Wollongong, mhadi@uow.edu.au

Follow this and additional works at: https://ro.uow.edu.au/eispapers1

Part of the Engineering Commons, and the Science and Technology Studies Commons

Research Online is the open access institutional repository for the University of Wollongong. For further information contact the UOW Library: research-pubs@uow.edu.au 


\title{
Performance evaluation of intermittently CFRP wrapped square and circularised square reinforced concrete columns under different loading conditions
}

\author{
Abstract \\ This paper presents the results of an experimental investigation on square and circularised square rein- \\ forced concrete (RC) columns intermittently wrapped with carbon fibre reinforced polymer (CFRP)under \\ different loading conditions. Twelve RC specimens consisting of eight square RC specimenswith \\ $150 \mathrm{~mm} 150 \mathrm{~mm}$ cross-section and $800 \mathrm{~mm}$ height and four circularised square RC specimenswith $212 \mathrm{~mm}$ \\ diameter and $800 \mathrm{~mm}$ height were tested under concentric axial load, eccentric axialload and four-point \\ flexural load. The test results showed that intermittent wrapping increased thestrength and ductility of \\ square RC specimens. The test results also showed that circularisation com-bined with intermittent \\ wrapping significantly improved the strength and ductility of square RC speci-mens. The experimental \\ axial load-bending moment interaction diagram showed that the bestperformance was achieved by \\ intermittently CFRP wrapped circularised square RC specimens.

\section{Keywords} \\ intermittently, columns, under, different, conditions, performance, loading, concrete, evaluation, reinforced, \\ circularised, square, wrapped, cfrp

\section{Disciplines} \\ Engineering | Science and Technology Studies

\section{Publication Details} \\ Mai, A. Duc., Sheikh, M. Neaz. \& Hadi, M. N. S. (2019). Performance evaluation of intermittently CFRP \\ wrapped square and circularised square reinforced concrete columns under different loading conditions. \\ Structure and Infrastructure Engineering: maintenance, management, life-cycle design and performance, \\ 15 (5), 696-710.
}




\title{
Performance Evaluation of Intermittently CFRP Wrapped Square and Circularized Square Reinforced Concrete Columns under Different Loading Conditions
}

\author{
Anh Duc Mai ${ }^{1}$, M. Neaz Sheikh ${ }^{2}$, Muhammad N.S. Hadi ${ }^{3}$ \\ ${ }^{1}$ Ph.D. Candidate, School of Civil, Mining and Environmental Engineering, University of \\ Wollongong, Wollongong, NSW 2522, Australia.E-mail: mad766@uowmail.edu.au \\ ${ }^{2}$ Associate Professor, School of Civil, Mining and Environmental Engineering, University of \\ Wollongong, Wollongong, NSW 2522, Australia.E-mail: msheikh@uow.edu.au \\ ${ }^{3}$ Associate Professor, School of Civil, Mining and Environmental Engineering, University of \\ Wollongong, Wollongong, NSW 2522, Australia (corresponding author). E-mail: \\ mhadi@uow.edu.au
}

\begin{abstract}
This paper presents the results of an experimental investigation on square and circularized square reinforced concrete $(\mathrm{RC})$ columns intermittently wrapped with carbon fibre reinforced polymer (CFRP) under different loading conditions. Twelve RC specimens consisting of eight square RC specimens with $150 \mathrm{~mm}$ x $150 \mathrm{~mm}$ cross-section and $800 \mathrm{~mm}$ height and four circularized square RC specimens with $212 \mathrm{~mm}$ diameter and 800 height were tested under concentric axial load, eccentric axial load and four-point flexural load. The test results showed that intermittent wrapping increased the strength and ductility of square RC specimens. The test results also showed that circularization combined with intermittent wrapping significantly improved the strength and ductility of square RC specimens. The experimental axial loadbending moment interaction diagram showed that the best performance was achieved by intermittently CFRP wrapped circularized square RC specimens.
\end{abstract}


Keywords: Column; Circularization; Shape modification; Carbon fibre; Intermittent wrapping; Concentric axial load; Eccentric axial load; Ductility.

\section{Introduction}

The use of fibre reinforced polymer (FRP) in strengthening existing deficient RC structures has been gaining increasing popularly in the construction industry (Durucan and An1l, 2017; Oller, Cobo, \& Marí, 2011; Shannag, Al-Akhras, \& Mahdawi, 2014). The popularity of FRP is due to its advantageous characteristics such as high tensile strength, lightweight, resistance to corrosion and ease of construction (La Malfa Ribolla et al., 2018; Sasmal, Khatri, \& Karusala, 2015; Shannag, et al., 2014). The FRP has been successfully applied for strengthening RC columns (Z. Wu, Zhang, \& Karbhari, 2010; Zou and Hong, 2011).

Wrapping concrete columns with FRP in the transverse direction brings the concrete to a state of tri-axial stress, which results in a significant increase in the strength and ductility of the columns (Lam and Teng, 2003; Tao, Yu, \& Zhong, 2008; Zou and Hong, 2011). A large number of research studies were carried out to investigate the confinement mechanics and stress-strain behaviour of FRP wrapped columns. However, most of the available studies on FRP wrapping were conducted on columns with full wrapping (Erdogan, Zohrevand, \& Mirmiran, 2013; Hadi, 2006; Jiang and Teng, 2013; Lam and Teng, 2003; Tan, 2002; Teng and Lam, 2002; Wang and Wu, 2008; Y. Wu and Zhou, 2010). Several studies were carried out to investigate the behaviour of intermittently FRP wrapped columns (Barros and Ferreira, 2008; Colomb, Tobbi, Ferrier, \& Hamelin, 2008; Dong, Wang, \& Guan, 2013; Hassan, Hodhod, Hilal, \& Bahnasaway, 2017; Hodhod, Hassan, Hilal, \& Bahnasawy, 2005; Maaddawy, 2009; Mai, Sheikh, \& Hadi, 2018; Park, Na, Chung, \& Feng, 2008; Pham, Hadi, \& Youssef, 2015; Triantafyllou, Rousakis, \& Karabinis, 2015). Intermittent wrapping has attracted research attention in recent years due to its advantageous features over full wrapping. The advantageous 
features of intermittent wrapping compared to full wrapping include the possibility of preventing the existence of air-voids between the concrete surface and the FRP (Park, et al., 2008), less consumption of FRP and adhesive (Triantafyllou, et al., 2015) and the ease of construction (Park, et al., 2008). However, ACI 440.2R-17 (2017) has not yet specified any guidelines for the use of intermittent wrapping in strengthening compression members because of the availability of inadequate research investigations on columns with intermittent wrapping. Meanwhile, FIB Bulletin 14 (2001) suggested a confinement effectiveness coefficient for the intermittent wrapping. In FIB Bulletin 14 (2001), the confinement effectiveness coefficient considers the reduction in the lateral confining pressure of intermittent wrapping compared to full wrapping. It is noted that confinement effectiveness coefficient was initially proposed by Mander, Priestley, \& Park (1988) to calculate the effective lateral confining pressure of steel ties.

The confinement effectiveness of FRP is significantly influenced by the geometry of the cross-section. The level of the confinement effectiveness of columns with square or rectangular cross-section is much lower than the level of the confinement effectiveness of columns with circular cross-section (Al-Salloum, 2007; Wang and Wu, 2008; Yang, Wei, Nanni, \& Dharani, 2004). This is due to the non-uniform distribution of the confining pressure on columns with square or rectangular cross-section compared to the uniform distribution of the confining pressure on columns with circular cross-section (Teng and Lam, 2002; Wang and $\mathrm{Wu}, 2008$; Yang, et al., 2004). It is noted that most of the RC building columns in practice have square or rectangular cross-section (Kim, Yi, Lee, Park, \& Kim, 2003; Tao, et al., 2008). For strengthening deficient square columns, intermittent wrapping could be an efficient and effective solution if the columns require a moderate improvement in the strength and ductility (Zeng, Guo, Gao, Li, \& Xie, 2017). Several studies investigated the behaviour of intermittently FRP wrapped square columns (Hodhod, et al., 2005; Maaddawy, 2009; Mostofinejad and Ilia, 
2014; Triantafyllou, et al., 2015; Zeng, et al., 2017). It was found that intermittent wrapping improved the strength and ductility of square columns (Hodhod, et al., 2005; Maaddawy, 2009; Triantafyllou, et al., 2015). However, the improvement in the strength of the square columns with intermittent wrapping was limited due to the non-uniform distribution of the lateral confining pressure on columns with square cross-section. Therefore, to increase the confinement effectiveness of intermittent wrapping of square columns, a few techniques were proposed including rounding the sharp corners, applying local reinforcement at the corners, using corner strip-batten wrapping and changing the square cross-section to a circular crosssection.

Rounding the sharp corners of square columns was proven to be an effective technique to increase the confinement effectiveness of full wrapping (Al-Salloum, 2007; Mostofinejad, Moshiri, \& Mortazavi, 2015; Wang and Wu, 2008; Yang, et al., 2004). It was also reported that the increase in the corner radii was directly proportional to the strength gained of fully FRP wrapped square columns (Wang and $\mathrm{Wu}, 2008$ ). Therefore, rounding the sharp corners was successfully applied for most of the available studies on intermittently FRP wrapped square columns (Hodhod, et al., 2005; Maaddawy, 2009; Triantafyllou, et al., 2015). However, the corner radius is usually limited to a small value because of the presence of internal steel reinforcement (Teng and Lam, 2002). Accordingly, the detrimental effect due to the stress concentration still remains in square columns leading to a limited confinement effectiveness generated by intermittent wrapping.

Another effective technique used to increase the confinement effectiveness of intermittent wrapping of square columns is the local reinforcement at the corners. This technique was implemented by fixing the FRP strips at the corners of square columns prior to the application of intermittent wrapping (Campione, 2006; Mostofinejad and Ilia, 2014). It was reported that local reinforcement alleviated the stress concentration at the corners of square columns, which 
postponed the premature rupture of FRP at the corners and increased the confinement effectiveness of intermittent wrapping (Campione, 2006; Mostofinejad and Ilia, 2014). However, FRP strips at the corners do not fully eliminate the stress concentration at the corners of intermittently FRP wrapped square columns due to the curvature of FRP strip at the corners of square columns.

The application of corner strip-batten wrapping is considered an effective technique to increase the confinement effectiveness of intermittent wrapping (Saljoughian and Mostofinejad, 2016a, 2016b). Saljoughian and Mostofinejad (2016a, 2016b) wrapped eight separate strips around the circumstance of square columns. Four out of the eight FRP strips used as corner strips were horizontally wrapped at the corners and the other four FRP strips used as battens were horizontally wrapped at the four flat sides of the square columns. Both ends of the FRP battens were bonded to two corner FRP strips at two overlapping zones. The corner strips combined with the battens worked as intermittent wrapping. It was found that the improvement in the strength and ductility due to the corner strip-batten wrapping was higher than the improvement in the strength and ductility of the conventional intermittent wrapping. Similar to the local reinforcement technique, the corner strip-batten wrapping does not fully eliminate the stress concentration at the corners of intermittently FRP wrapped square columns. In addition, the use of local reinforcement and corner strip-batten wrapping on site can be a complicated process (Saljoughian and Mostofinejad, 2016b). Therefore, changing the square columns to circular columns (shape modification) before applying the intermittent wrapping may be considered as an appropriate technique for the efficient use of CFRP strips.

The concept of shape modification was initially proposed by Priestley, Seible, Xiao, \& Verma (1994). In Priestley, et al. (1994), rectangular columns were bonded with precast concrete bolsters to obtain elliptical columns. Thereafter, the performance of FRP wrapped circularized square columns (square cross-section modified to circular cross-section) was 
investigated in several research studies (Hadi, Jameel, \& Sheikh, 2017; Hadi, Pham, \& Lei, 2013; Jameel, Sheikh, \& Hadi, 2017; Kim, et al., 2003; Pham, Doan, \& Hadi, 2013; Youssf, Hassanli, \& Mills, 2017; Zeng, et al., 2017). It was reported that the circularization led to a substantial improvement in the strength and ductility of the columns due to the elimination of the stress-concentration at the corners. However, most of the available studies investigated the performance of circularized square concrete cylinders (Jameel, et al., 2017; Kim, et al., 2003; Youssf, et al., 2017), circularized square columns (columns without steel reinforcement) (Zeng, et al., 2017) or circularized square RC columns (Hadi, et al., 2017; Hadi, et al., 2013; Pham, et al., 2013) with full wrapping. Only one study investigated the performance of circularized square columns (columns without steel reinforcement) (Zeng, et al., 2017) with intermittent wrapping in which the columns were subjected to only concentric axial loads. It is noted that, in practice, RC columns are usually subjected to eccentric axial loads due to the position of the columns in the structure or unintentional eccentric axial loads. The above literature review shows that no study yet investigated the behaviour of intermittently FRP wrapped circularized square RC columns under concentric axial load and eccentric axial loads.

This experimental study investigates the performance of intermittently CFRP wrapped square and circularized square RC columns under different loading conditions. Twelve RC specimens including eight square RC specimens and four circularized square RC specimens were tested under concentric axial load, eccentric axial load and four-point flexural load.

\section{Experimental Program}

\subsection{Test Specimens}

In this study, $12 \mathrm{RC}$ specimens including eight square RC specimens and four circularized square RC specimens were prepared and tested. The dimensions of the square RC specimens were $150 \mathrm{~mm}$ x $150 \mathrm{~mm}$ cross-section and $800 \mathrm{~mm}$ height. The dimensions of the square RC 
specimens after circularization (circularized square RC specimens) were $212 \mathrm{~mm}$ diameter and $800 \mathrm{~mm}$ height. The dimensions of the test specimens were chosen to simulate the behaviour of a short column and to suit the capacity of the $5000 \mathrm{kN}$ Denison Compression Testing Machine (DCTM) in the Structural Engineering Laboratory at the University of Wollongong, Australia.

All specimens were longitudinally reinforced with four $12 \mathrm{~mm}$ diameter deformed steel (N12) bars and transversely reinforced with ten $6 \mathrm{~mm}$ diameter plain steel (R6) bars having 80 $\mathrm{mm}$ centre-to-centre spacing. A clear concrete cover of $20 \mathrm{~mm}$ was maintained at the top, the bottom and at the four sides of the specimens. The corners of the CFRP wrapped square RC specimens were rounded to $20 \mathrm{~mm}$ radius to increase the confinement effectiveness (ACI 440.2R-17 2017; FIB Bulletin 14 2001). The corners of non-wrapped square RC specimens were also rounded to $20 \mathrm{~mm}$ radius along the height of the specimens to wrap the top and bottom of the specimens with CFRP in order to prevent premature failure during the test (Hadi, et al., 2013; Hadi and Youssef, 2016).

Twelve RC specimens were divided into three groups with four specimens in each group. The first two groups (Groups SN and SI) included eight square RC specimens. The third group (Group CI) included four circularized square RC specimens. In each group, the first three specimens were considered as column specimens and tested under concentric, $15 \mathrm{~mm}$ eccentric and $25 \mathrm{~mm}$ eccentric axial load. The last specimen of each group was considered as a beam specimen (column under pure bending condition) and tested under four-point flexural load. The details of the test specimens are presented in Figure 1.

The specimens of Group SN were non-wrapped specimens, which were used as the reference specimens. Specimens of Group SI were intermittently wrapped with three layers of CFRP strips. In order to maximize the confinement effect of the intermittent wrapping, the CFRP strips were designed to be located in between the steel ties to consider the dual 
confinement generated by CFRP strips and steel ties (Barros and Ferreira, 2008; Triantafyllou, et al., 2015). The width of the CFRP strips was also chosen to be the same as the clear spacing based on the available experimental studies on intermittent wrapping (Barros and Ferreira, 2008; Colomb, et al., 2008; Hassan, et al., 2017; Mostofinejad, et al., 2015; Saljoughian and Mostofinejad, 2016a, 2016b). Accordingly, the width and clear spacing of the CFRP strips for the specimens of Group SI were $40 \mathrm{~mm}$, which were equal to half of the centre-to-centre spacing of the steel ties.

The circularized square RC specimens of Group CI were constructed by bonding four precast concrete segments to the four sides of the square RC specimens to obtain a circular cross-section. Then the specimens were intermittently wrapped with three layers of CFRP strips. The width of the CFRP strips used for the specimens of Group CI was $50 \mathrm{~mm}$. It is noted that for the specimens of Groups SI and CI, one of the CFRP strips was designed to be located at the mid-height of intermittently CFRP wrapped RC specimens. This was done to prevent the failure at the mid-height of the specimens, which was observed as the usual failure location of intermittently FRP wrapped RC columns (Hodhod, et al., 2005; Mostofinejad and Ilia, 2014; Saljoughian and Mostofinejad, 2016a, 2016b).

The notation of each specimen includes three parts as presented in Table 1. The first part presents the cross-sectional shape of the specimen. The second part presents the wrapping scheme of the specimen. The third part presents the loading condition of the specimen. The first part is either the letter $\mathrm{S}$ or $\mathrm{C}$, in which $\mathrm{S}$ and $\mathrm{C}$ refer to the square and circular crosssection, respectively. The second part is either the letter $\mathrm{N}$ or I, in which $\mathrm{N}$ and I refer to nonwrapping and intermittent wrapping, respectively. The third part is either the numbers of 0,15 , 25 , or the letter $\mathrm{B}$, in which $0,15,25$, and $\mathrm{B}$ refer to concentric axial load, $15 \mathrm{~mm}$ eccentric axial load, $25 \mathrm{~mm}$ eccentric axial load and four-point flexural load, respectively. 


\subsection{Preparation of specimens}

All steel cages were prepared by assembling four N12 longitudinal steel bars with ten R6 plain steel ties having $80 \mathrm{~mm}$ centre-to-centre spacing. To ensure $20 \mathrm{~mm}$ concrete clear cover at the sides and at the top and bottom of the specimens, steel ties with $110 \mathrm{~mm} \times 110 \mathrm{~mm}$ outer crosssectional dimension were assembled with the longitudinal reinforcement of $760 \mathrm{~mm}$ height.

The plywood formwork was used for casting square RC specimens, whereas the polyvinyl chloride (PVC) formwork was used for casting concrete segments. Styrofoam with $20 \mathrm{~mm}$ radius was attached at the four corners of the plywood formwork to generate the rounded corners for the square RC specimens of Groups SN and SI. The PVC formwork for the concrete segments was fabricated by fixing a styrofoam prism with $800 \mathrm{~mm}$ height and $150 \mathrm{~mm} \times 150$ mm cross-section inside the PVC pipe. The PVC pipes had 212 inner diameter and $10 \mathrm{~mm}$ thickness. Figure 2 shows the details of the formworks before casting the concrete.

The square RC specimens and the concrete segments were cast from a single batch of ready-mix normal strength concrete, which was provided by a local concrete supplier. After one day of casting, the RC specimens and concrete segments were cured by watering them twice every working day and then covering them with wet hessian rugs and plastic sheets to keep the specimen moist. The formworks of the square RC specimens and concrete segments were stripped off on the $14^{\text {th }}$ day after casting. The square RC specimens and concrete segments were cured until the $28^{\text {th }}$ day after casting then the square $\mathrm{RC}$ specimens and concrete segments were kept at the laboratory in room temperature until the day of testing.

To manufacture the circularized square RC specimens, the square cross-section of RC specimens was changed to a circular cross-section by bonding four precast concrete segments to the four flat sides of the square RC specimens. The concrete bonding agent was a mixture of slow hardener, epoxy resin and silica microsphere with the proportion of 1:5:10 (Hadi, et al., 2013; Pham, et al., 2013). The concrete segments were bonded into the square RC specimen 
by rubber straps. The rubber straps were attached on the circularized square $\mathrm{RC}$ specimens for at least 7 days to allow the bonding agent to dry. Figure 3 shows the bonding process of circularized square RC specimens.

The wet layup procedure was applied to wrap the specimens with CFRP. The CFRP bonding agent was a mixture of slow hardener and epoxy resin with a proportion of 1:5. The CFRP fibres were oriented in the hoop direction. To ensure a sufficient bonding length, an overlapping zone of $100 \mathrm{~mm}$ length was provided for each CFRP strip.

\subsection{Material Properties}

The tensile properties of the N12 deformed steel bars and the R6 plain steel bars were determined by testing three samples with $500 \mathrm{~mm}$ length from each type of steel bars, as specified in AS 1391-2007 (2007). The average yield tensile strengths of N12 deformed steel bars and R6 plain steel bars were 568 and $517 \mathrm{MPa}$, respectively. Three standard concrete cylinders with $100 \mathrm{~mm}$ diameter and $200 \mathrm{~mm}$ height were tested to determine the compressive strength of the concrete, as specified in AS 1012.9:2014 (2014). The average compressive strength of concrete on the $28^{\text {th }}$ day was $36 \mathrm{MPa}$. The CFRP used to wrap the specimens had $300 \mathrm{~g} / \mathrm{m}^{2}$ unit weight and $0.167 \mathrm{~mm}$ nominal thickness. To determine the tensile properties of CFRP, five CFRP coupons with $22.75 \mathrm{~mm}$ width and $250 \mathrm{~mm}$ length were tested according to ASTM D3039/D3039M-14 (2008). The average tensile strength, corresponding tensile strain and modulus of elasticity in tension of CFRP were $3726 \mathrm{MPa}, 1.55 \%$ and $240.43 \mathrm{GPa}$, respectively.

\subsection{Test setup and Instrumentation}

All the column and beam specimens were tested by the DCTM. Two layers of $100 \mathrm{~mm}$ wide CFRP were used to additionally wrap the top and bottom of the column specimens. This additional wrapping was implemented to avoid the premature failure due to stress 
concentrations at the top and bottom of the specimens during the test. Also, the surfaces of the top and bottom of the column specimens were capped with high strength plaster for a uniform distribution of the applied axial load.

Figure 4 shows the test set up of the column and beam specimens. The axial load generated by the DCTM was applied on the column specimens through loading heads. Each loading head consisted of an adaptor plate and a ball joint plate. Two types of adaptor plates were used for the square specimens and circularized square specimens. The adaptor plate was attached directly to the surface of the column specimens. For concentrically loaded column specimens, only the adaptor plate was used. For eccentrically loaded column specimens, both the adaptor plate and the thick plate were used. Two linear variable differential transducers (LVDTs) mounted at the two opposite corners of the bottom loading plate of the DCTM were used to measure the axial deformation of the specimens. The lateral deformation at the mid-height of the eccentrically loaded specimens was measured by a laser triangulation. A data logger connected a computer recorded the test data at every two seconds.

The four-point flexural load was applied on the beam specimens through a pair of steel rigs. The bottom steel rig with a clear span of $700 \mathrm{~mm}$ and the top steel rig with a clear span of $233.3 \mathrm{~m}$ were placed under and over the beam specimens to generate four-point flexural load. Accordingly, the beam specimens were tested under a clear span of $700 \mathrm{~mm}$ and two shear spans of $233 \mathrm{~mm}$. A laser triangulation was placed under the bottom rig to measure the midspan deflection of the beam specimens during the test.

To prevent the movement of the specimens at the beginning of the test, each of the column and beam specimens was initially preloaded at a rate of $2 \mathrm{kN} / \mathrm{s}$ up to approximately $100 \mathrm{kN}$ ( $10 \%$ of the ultimate axial load) then unloaded at the same rate to $20 \mathrm{kN}$. Afterwards, the test was resumed and continued until the failure of the specimens with deformation controlled loadings at a rate of $0.3 \mathrm{~mm} / \mathrm{min}$. 


\section{Experimental results and discussions}

\subsection{Failure modes of test specimens}

The failure modes of the specimens tested under concentric axial load and four-point flexural load are presented in Figure 5. The failure of Specimen $\mathrm{SN}-0$ was due to the spalling of the concrete cover around the mid-height of the specimen followed by buckling of the longitudinal steel bars. Specimens SI-0 and CI-0 experienced similar failure modes with cracking of the concrete cover in the non-wrapped region and the rupture of CFRP strip around the mid-height of the specimens. Cracking of the concrete cover started at the non-wrapped region around the mid-height then propagated to the two ends of Specimens SI-0 and CI-0. Similar observations of cracking of the concrete cover in the non-wrapped region were also reported in previous research studies (Matthys, Toutanji, Audenaert, \& Taerwe, 2005; Saljoughian and Mostofinejad, 2016b; Zeng, et al., 2017). Afterwards, Specimens SI-0 and CI-0 experienced the rupture of the CFRP strip around the mid-height of the specimens, which was followed by crushing of the concrete and buckling of the longitudinal steel bars.

For Specimen SI-0, the rupture of CFRP strip occurred at one of the corners indicating stress concentrations at the corners of the specimen. The rupture of CFRP strip at one of the corners of the square specimens was also observed in Saljoughian and Mostofinejad (2016b) and Triantafyllou, et al. (2015). For Specimen CI-0, the rupture of CFRP strip occurred at random positions indicating the uniform distribution of the confining pressure. A similar failure of intermittently FRP wrapped circularized square column was also observed in Zeng, et al. (2017). It is noted that the concrete segments were still intact with the concrete core of the circularized square RC specimen after failing, which illustrated a good bonding between the concrete segments and the square RC specimen. A good bonding was also observed in Pham, et al. (2013) when the concrete segments were bonded to the square RC specimen using a similar bonding agent. In contrast, the separation between the concrete segments and the 
concrete column (column without steel reinforcement) due to the incompatibility between these two parts was observed in Zeng, et al. (2017).

For eccentrically loaded specimens, Specimens SN-15 and SN-25 failed due to the crushing and spalling of the concrete cover in the non-wrapped region on the compression side at the mid-height and below the mid-height of the specimens. The buckling of longitudinal steel bars on the compression side and the transverse cracking of the concrete on the tension side was observed in Specimens SN-15 and SN-25. The failure of the specimens of Groups SI and CI under $15 \mathrm{~mm}$ and $25 \mathrm{~mm}$ eccentric axial load was similar. The failure of Specimens SI15, SI-25, CI-15 and CI-25 started with the cracking of the concrete cover in the non-wrapped region on the compression side at the mid-height and was governed by the rupture of the CFRP strip on the compression side at the mid-height of the specimens. The rupture of CFRP strip of Specimen SI-15 occurred at one of the corners, which was consistent with the observation in previous studies (Hassan, et al., 2017; Saljoughian and Mostofinejad, 2016b). Whereas, the rupture of the CFRP strip of Specimens CI-15 and CI-25 occurred at random positions. For Specimen SI-25, no rupture of CFRP strip was observed.

The failure of Specimens SN-F, SI-F and CI-F started with hairline vertical cracks at the midspan on the tension side due to flexural stress. Then, multiple hairline vertical cracks occurred between the two loading points for Specimen SN-F. For Specimens SI-F and CI-F, the multiple hairline vertical cracks occurred in the non-wrapped region between the two loading points. The hairline vertical cracks were then opened widely and propagated from the tension side to the compression side of the specimens. The failure of Specimens SN-F, SI-F and CI-F was finally governed by the rupture of tensile longitudinal steel bars, which was accompanied by an explosive sound. 


\subsection{Load-deformation behaviour}

The ductility $(\mu)$ of the test specimens was calculated as the ratio of the ultimate deformation to the yield deformation (Hadi, et al., 2017). The ultimate deformation of the specimens was considered the deformation in the descending part of the load-deformation response, which corresponded to $85 \%$ of the ultimate load (Hadi, et al., 2017). The yield deformation of the specimens was considered the deformation corresponding to the intersection point between two straight lines (Foster and Attard, 1997; Hadi, et al., 2017). The first straight line was drawn from the origin to the point in the linear ascending part of the load-deformation response presenting 0.75 times the first peak load. The second straight line, which was a horizontal line, passed through the first peak load of the load-deformation response. The experimental results of the test specimens are presented in Table 2 and Table 3.

As can be seen in Figure 6, the axial load-axial deformation responses of Specimens SN0 and SI-0 revealed similar linear ascending responses until the ultimate axial load of Specimen SN-0. The similar linear ascending responses of Specimens SN-0 and SI-0 revealed a similar stiffness of the specimens, which represented the behaviour of non-confined concrete (Fam and Rizkalla, 2001; Teng and Lam, 2004). The gradient of the linear ascending response of Specimen CI-0 was higher than the gradient of the linear ascending responses of Specimens SN-0 and SI-0, which indicated a higher stiffness of Specimen CI-0 compared to Specimens SN-0 and SI-0. The stiffness of Specimen CI-0 was higher than the stiffness of Specimens SN0 and SI-0, which was because of a higher cross-sectional area of Specimen CI-0 compared to Specimens SN-0 and SI-0. The axial load-axial deformation responses of Specimens SI-0 and CI-0 showed a bi-linear response with the second ascending response after the first linear ascending response. The second ascending axial load-axial deformation responses of Specimens SI-0 and CI-0 indicated the confinement effect of the CFRP wrapping on the behaviour of the specimens after the cracking of concrete. Unlike Specimens SI-0 and CI-0, 
the axial load-axial deformation response of Specimen $\mathrm{SN}-0$ showed a descending response after the first linear ascending response due to the spalling of the concrete cover.

The axial load-axial deformation responses of Specimens SI-0 and CI-0 exhibited two peak axial loads due to a slight decrease of the axial load after the first peak axial load. The decrease of the axial load was due to the cracking of the concrete cover in the non-wrapped region. The decrease of the axial load of Specimen SI-0 after the first peak axial load was consistent with the observations in Saljoughian and Mostofinejad (2016a). After experiencing a slight decrease of the axial load, Specimen SI-0 experienced a slight increase of the axial load, whereas Specimen CI-0 experienced a significant increase of the axial load. The increase of the axial load to the second peak axial load of Specimens SI-0 and CI-0 revealed that the gain in the axial load due to CFRP confinement was higher than the degradation of the axial load due to the cracking of the concrete cover in the non-wrapped region. The slope of the axial load-axial deformation response of Specimen CI-0 after the first peak axial load was steeper than that of Specimen SI-0. This indicated the effectiveness of the circularization with a uniform distribution of the confining pressure on Specimen CI-0 instead of non-uniform distribution of the confining pressure on Specimen SI-0.

The highest ultimate axial load was attained by Specimen CI-0 $(2268.5 \mathrm{kN})$, followed by Specimen SI-0 (1204.4 kN) and Specimen SN-0 (993.5 kN). With the same wrapping scheme and number of layers of CFRP for Specimens SI-0 and CI-0, the increase in the ultimate axial load of Specimen CI relative to Specimen SI-0 was $88.4 \%$. The higher ultimate axial load of Specimen CI-0 compared to Specimen SI-0 indicated the effectiveness of the circularization in improving the confinement effect of intermittent wrapping. The increase in the ultimate axial load of Specimen SI-0 relative to Specimen SN-0 was $21.2 \%$. The higher ultimate axial load of Specimens CI-0 and SI-0 compared to Specimen SN-0 indicated the effectiveness of CFRP wrapping in improving the load-carrying capacity of the column specimens. As can be seen in 
Table 2, the ductility of the square RC specimens was significantly increased by wrapping with CFRP. The increase in the ductility of Specimens CI-0 and SI-0 relative to Specimen SN-0 was $253.1 \%$ and $367.6 \%$, respectively.

Figures 7 and 8 show the axial load-axial deformation and axial load-lateral deformation responses of the specimens under $15 \mathrm{~mm}$ and $25 \mathrm{~mm}$ eccentric axial load, respectively. Generally, the axial load-axial deformation and axial load-lateral deformation responses of the eccentrically loaded specimens exhibited one peak axial load with the descending axial loadaxial deformation and the axial load-lateral deformation responses after the peak axial load. Similar axial load-axial deformation and axial load-lateral deformation responses of intermittently CFRP wrapped square RC specimens under eccentric axial load were observed in Saljoughian and Mostofinejad (2016a, 2016b). The descending axial load-axial deformation and axial load-lateral deformation responses of eccentrically loaded specimens relative to the ascending axial load-axial deformation responses of concentrically loaded specimens indicated the reduction of the level of confinement effect of the FRP wrapping due to the increase of the eccentricity. The decrease of the axial load of eccentrically loaded specimens was due to the crushing or spalling of concrete cover in the non-wrapped region on the compression side of the specimens. Under the same axial load eccentricity, the slopes of the first ascending axial load-axial deformation and axial load-lateral deformation responses of Specimens SN and SI were similar. The slopes of the first ascending axial load-axial deformation and axial loadlateral deformation responses of Specimen CI were steeper compared to those of Specimens SN and SI for the same axial load eccentricity.

Under $15 \mathrm{~mm}$ eccentric axial load, Specimen CI-15 attained the highest ultimate axial load $(1667.9 \mathrm{kN})$, followed by Specimens SI-15 $(905.1 \mathrm{kN})$ and SN-15 $(731.8 \mathrm{kN})$. The increase in the ultimate axial load of Specimen CI-15 relative to Specimen SI-15 was $84.3 \%$, although a similar amount of CFRP was used for both Specimens CI-15 and SI-15. The increase in the 
ultimate axial load of Specimen SI-15 relative to Specimen SN-15 was 23.7\%. The increase in the ductility of Specimens CI-15 and SI-15 compared to Specimen SN-15 was $138.5 \%$ and $85.6 \%$, respectively. Under $25 \mathrm{~mm}$ eccentric axial load, the highest ultimate axial load was obtained by Specimen CI-25 (1487.5 kN), followed by Specimens SI-25 (742.8 kN) and SN$25(630.2 \mathrm{kN})$. The increase in the ultimate axial load of Specimen CI-25 relative to Specimen SI-25 was $100.3 \%$. The increase in the ultimate axial load of Specimen SI-25 relative to Specimen SN-25 was 17.9\%. The increase in the ductility of Specimens CI-25 and SI-25 compared to Specimen SN-25 was $330.1 \%$ and $96.2 \%$, respectively.

The flexural load-midspan deflections responses of the specimens tested under four-point flexural load are shown in Figure 9. The flexural load-midspan deflection responses of Specimens CI-F and SI-F showed two peak flexural loads with an ascending response after the first peak flexural load. However, the flexural load-midspan deflection response of Specimen SN-F showed one peak flexural load with a descending response after the first peak flexural load. The ascending response after the first peak flexural load of the flexural load-midpsan deflection responses of Specimens CI-F and SI-F could be due to the confinement effect of CFRP in the compressive concrete of the specimens. A similar ascending flexural load-midspan deflection response after the first peak of CFRP wrapped circularized square RC specimen was also observed in previous studies (Hadi, et al., 2017; Hadi, et al., 2013).

As shown in Table 3, Specimen CI-F attained the highest ultimate flexural load (218.1 $\mathrm{kN})$, followed by Specimens SI-F $(160.4 \mathrm{kN})$ and SN-F $(126.1 \mathrm{kN})$. The increase in the ultimate flexural load of Specimen CI-F compared to Specimens SI-F and SN-F was 36.3\% and 73\%, respectively. The ultimate flexural load of Specimen SI-F was $26.9 \%$ higher than that of Specimen SN-F. In contrast to the specimens tested under concentric and eccentric axial loads, the ductility of Specimens CI-F and SI-F was lower than the ductility of Specimen SN-F. The 
ductility of Specimens CI-F and SI-F was $20.8 \%$ and $37.3 \%$ lower than the ductility of Specimen SN-F, respectively.

\subsection{Axial stress-axial deformation behaviour}

As shown in Table 2, the ultimate axial load of the square RC specimens was significantly increased by the circularization of the square cross-section before wrapping with CFRP. The highest ultimate axial load achieved by the specimens of Group CI was predominantly due to the higher cross-sectional area and higher confinement effect. To exclude the contribution of the cross-sectional area in the ultimate axial load and to evaluate the increase in the confinement effect due to the circularization, the axial stress-axial deformation responses of the specimens tested under concentric axial load was plotted.

As shown in Figure 10, the first linear ascending axial stress-axial deformation responses of Specimens SN-0, SI-0 and CI-0 were similar before the cracking of concrete cover, which illustrated similar stiffness of the specimens. The axial stress of Specimen SN-0 suddenly dropped after the ultimate axial stress due to the spalling of concrete cover. The axial stresses of both Specimens SI-0 and CI-0 slightly decreased after the yield axial stress due to the cracking of the concrete cover in the non-wrapped region. The slope of the axial stress-axial deformation response of Specimen CI-0 after the yield was steeper than the slope of the axial stress-axial deformation response of Specimen SI-0 after the yield. This indicated that the level of confinement effect due to CFRP wrapping on Specimen CI-0 was higher than that on Specimen SI-0. Consequently, the ultimate axial stress of Specimen CI-0 was higher than the ultimate axial stress of Specimen SI-0. The higher ultimate axial stress of intermittently CFRP wrapped circularized square specimen compared to intermittently CFRP wrapped square specimen was consistent with the observation in Zeng, et al. (2017). The ultimate axial stresses of Specimens CI-0 (64.2 MPa) and SI-0 (54.4 MPa) were 31.6\% and 11.5\%, respectively higher 
than the ultimate axial stress of Specimen SN-0 (48.8 MPa). The increase in the ultimate axial stress of Specimen CI-0 relative to Specimen SI-0 was $9.8 \%$.

\subsection{Experimental axial load and bending moment interaction diagrams}

The experimental axial load-bending moment interaction (P-M) diagrams of the test specimens were constructed based on four points. Each point of the P-M diagrams consists of the ultimate axial load and corresponding bending moment. The first point represents the capacity of concentrically loaded specimens. The second and third points represent the capacity of the 15 $\mathrm{mm}$ and $25 \mathrm{~mm}$ eccentrically loaded specimens, respectively. The fourth point represents the capacity of the specimens tested under four-point flexural load. The experimental bending moment $\left(M_{u}\right)$ at the mid-height of eccentrically loaded specimens was calculated using Eq. 1.

$$
M_{u}=P_{u}(e+\delta)
$$

where $P_{u}$ is the ultimate axial load, $e$ is the axial load eccentricity and $\delta$ is the lateral deformation at the mid-height of column specimens corresponding to the ultimate axial load.

The experimental bending moment $\left(M_{u}\right)$ at the midspan of beam specimens was calculated using Eq. 2.

$$
M_{u}=\frac{1}{6} P_{u} L
$$

where $P_{u}$ is the ultimate flexural load and $L$ is the distance between the two supports of the beam specimens. For this study, $L$ is $700 \mathrm{~mm}$.

As can be seen in Figure 11, under all loading conditions, the highest ultimate axial load and bending moment were achieved by the specimens of Group CI. The specimens of Group SI attained higher ultimate axial load than the specimens of Group SN under concentric, 15 $\mathrm{mm}$ eccentric and $25 \mathrm{~mm}$ eccentric axial load. The bending moment of the specimens of Group CI was $136.3 \%, 102.7 \%$ and $35.8 \%$ higher than the bending moment of the specimens of Group 
SI under $15 \mathrm{~mm}$ eccentric load, $25 \mathrm{~mm}$ eccentric axial load and four-point flexural load, respectively. The bending moment of the specimens of Group SI was 31.3\%, 27.7\% and 27.2\% higher than the bending moment of the specimens of Group SN under $15 \mathrm{~mm}$ eccentric load, $25 \mathrm{~mm}$ eccentric axial load and four-point flexural load, respectively. It is clear that the circularization of the square RC specimens before wrapping with CFRP improved significantly the ultimate axial load and bending moment of the square RC specimens.

\section{Conclusions}

Based on the test results from twelve RC specimens, the following conclusions are drawn:

1. Intermittent wrapping with CFRP significantly increased the strength and ductility of square RC specimens under different loading conditions.

2. For intermittent wrapping, the circularization of square RC specimens significantly increased the ultimate axial load and ductility of the square RC specimens. The increase in the strength of the specimens of Group CI relative to the specimens of Group SI was $88.4 \%, 84.3 \%, 100.2 \%$ and $36.3 \%$ under concentric axial load, $15 \mathrm{~mm}$ eccentric axial load, $25 \mathrm{~mm}$ eccentric axial load and four-point flexural load, respectively. Although the ductility of the specimens of Group CI was lower than the ductility of the specimens of Group SI under concentric axial load, the ductility of the specimens of Group CI was $39.2 \%, 136 \%$ and $26.3 \%$ higher under $15 \mathrm{~mm}$ eccentric axial load, $25 \mathrm{~mm}$ eccentric axial load and four-point flexural load, respectively.

3. Intermittently CFRP wrapped circularized square RC specimens obtained the highest bending moment capacity under all loading conditions, which were followed by intermittently CFRP wrapped square RC specimens and non-wrapped square RC specimens. 


\section{Acknowledgements}

The authors would like to thank the technical staff of the Structural Engineering Laboratory at the University of Wollongong, Australia for the technical assistance. The authors also acknowledge the financial support from the University of Wollongong, Australia. The first author is immensely grateful to the Australian Government for the scholarship of his Ph.D. program.

\section{References}

ACI (American Concrete Institute). (2017). Guide for the Design and Construction of Externally Bonded FRP Systems for Strengthening Concrete Structures ACI 440.2R-17: USA.

Al-Salloum, Y. A. (2007). Influence of edge sharpness on the strength of square concrete columns confined with FRP composite laminates. Composites Part B: Engineering, 38(56), 640-650. doi:10.1016/j.compositesb.2006.06.019

AS (Australian Standard). (2007). Metallic materials-Tensile testing at ambient temperature AS 1391-2007: Standards Australia Limited, Australia.

AS (Australian Standard). (2014). Methods of testing concrete: Method 9: Compressive strength tests-Concrete, mortar and grout specimens Australian Standard AS 1391-2007: Standards Australia Limited, Australia.

ASTM (American Society for Testing and Materials). (2008). Standard Test Method for Tensile Properties of Polymer Matrix Composite Materials ASTM D3039/D3039M-14: ASTM International, USA.

Barros, J. A. O., \& Ferreira, D. R. S. M. (2008). Assessing the Efficiency of CFRP Discrete Confinement Systems for Concrete Cylinders. Journal of Composites for Construction, 12(2), 134-148. doi:10.1061/(ASCE)1090-0268(2008)12:2(134)

Campione, G. (2006). Influence of FRP wrapping techniques on the compressive behavior of concrete prisms. Cement and Concrete Composites, 28(5), 497-505. doi:10.1016/j.cemconcomp.2006.01.002 
Colomb, F., Tobbi, H., Ferrier, E., \& Hamelin, P. (2008). Seismic retrofit of reinforced concrete short columns by CFRP materials. Composite Structures, 82(4), 475-487. doi:10.1016/j.compstruct.2007.01.028

Dong, J. F., Wang, Q. Y., \& Guan, Z. W. (2013). Structural behaviour of recycled aggregate concrete filled steel tube columns strengthened by CFRP. Engineering Structures, 48, 532 542. doi:10.1016/j.engstruct.2012.11.006

Durucan, C., \& Anıl, Ö. (2017). Nonlinear 3D finite element simulation of reinforced concrete flat plates retrofitted with externally bonded CFRP strips. Structure and Infrastructure Engineering, 13(9), 1198-1211. doi:10.1080/15732479.2016.1257645

Erdogan, H., Zohrevand, P., \& Mirmiran, A. (2013). Effectiveness of externally applied CFRP stirrups for rehabilitation of slab-column connections. Journal of Composites for Construction, 17(6), 04013008. doi:10.1061/(ASCE)CC.1943-5614.0000389

Fam, A. Z., \& Rizkalla, S. H. (2001). Confinement model for axially loaded concrete confined by circular fiber-reinforced polymer tubes. ACI Structural Journal, 98(4), 451-461.

FIB (The International Federation for Structure Concrete). (2001). Externally bonded FRP reinforcement for RC structures FIB Bulletin 14: Switzerland.

Foster, S. J., \& Attard, M. M. (1997). Experimental tests on eccentrically loaded high-strength concrete columns. ACI Structural Journal, 94(3), 295-303.

Hadi, M. N. S. (2006). Behaviour of FRP wrapped normal strength concrete columns unde $\begin{array}{llll}\text { eccentric loading. } & \text { Composite } & \text { Structures, } & \text { 72(4), }\end{array}$ doi:10.1016/j.compstruct.2005.01.018

Hadi, M. N. S., Jameel, M. T., \& Sheikh, M. N. (2017). Behavior of Circularized Hollow RC Columns under Different Loading Conditions. Journal of Composites for Construction, 21(5), 04017025. doi:10.1061/(ASCE)CC.1943-5614.0000808

Hadi, M. N. S., Pham, T. M., \& Lei, X. (2013). New Method of Strengthening Reinforced Concrete Square Columns by Circularizing and Wrapping with Fiber-Reinforced Polymer or Steel Straps. Journal of Composites for Construction, 17(2), 229-238. doi:10.1061/(ASCE)CC.1943-5614.0000335 
Hadi, M. N. S., \& Youssef, J. (2016). Experimental investigation of GFRP-reinforced and GFRP-encased square concrete specimens under axial and eccentric load, and four-point bending test. Journal of Composites for Construction, 20(5), 04016020. doi:10.1061/(ASCE)CC.1943-5614.0000675

Hassan, W. M., Hodhod, O. A., Hilal, M. S., \& Bahnasaway, H. H. (2017). Behavior of eccentrically loaded high strength concrete columns jacketed with FRP laminates. $\begin{array}{llll}\text { Construction } \quad \text { and } \quad \text { Building } \quad \text { Materials, } & \text { 138, }\end{array}$ doi:10.1016/j.conbuildmat.2017.02.016

Hodhod, O. A., Hassan, W., Hilal, M. S., \& Bahnasawy, H. (2005). Strength and ductility of biaxially loaded high strength RC short square columns wrapped with GFRP jackets. Structural Engineering and Mechanics, 20(6), 727-745. doi:10.12989/sem.2005.20.6.727

Jameel, M. T., Sheikh, M. N., \& Hadi, M. N. S. (2017). Behaviour of circularized and FRP wrapped hollow concrete specimens under axial compressive load. Composite Structures, 171, 538-548. doi:10.1016/j.compstruct.2017.03.056

Jiang, T., \& Teng, J. G. (2013). Behavior and design of slender FRP-confined circular RC columns. Journal of Composites for Construction, 17(4), 443-453. doi:10.1061/(ASCE)CC.1943-5614.0000333

Kim, J. H. J., Yi, S. T., Lee, S. H., Park, S. K., \& Kim, J. K. (2003). Compressive behaviour of CFS strengthened concrete specimens with various cross-sectional shapes and laminations. Magazine of Concrete Research, 55(5), 407-418. doi:10.1680/macr.55.5.407.37592

La Malfa Ribolla, E., Rezaee Hajidehi, M., Rizzo, P., Fileccia Scimemi, G., Spada, A., \& Giambanco, G. (2018). Ultrasonic inspection for the detection of debonding in CFRPreinforced concrete. Structure and Infrastructure Engineering, 14(6), 807-816. doi:10.1080/15732479.2017.1384843

Lam, L., \& Teng, J. G. (2003). Design-oriented stress-strain model for FRP-confined concrete. Construction and Building Materials, 17(6-7), 471-489. doi:10.1016/S09500618(03)00045-X

Maaddawy, T. E. (2009). Strengthening of Eccentrically Loaded Reinforced Concrete Columns with Fiber-Reinforced Polymer Wrapping System: Experimental Investigation and 
Analytical Modeling. Journal of Composites for Construction, 13(1), 13-24. doi:10.1061/(ASCE)1090-0268(2009)13:1(13)

Mai, A. D., Sheikh, M. N., \& Hadi, M. N. S. (2018). Investigation on the behaviour of partial wrapping in comparison with full wrapping of square RC columns under different loading conditions. Construction and Building Materials, 168, 153-168. doi:10.1016/j.conbuildmat.2018.02.003

Mander, J. B., Priestley, M. J., \& Park, R. (1988). Theoretical stress-strain model for confined concrete. Journal of Structural Engineering, 114(8), 1804-1826. doi:10.1061/(ASCE)0733-9445(1988)114:8(1804)

Matthys, S., Toutanji, H., Audenaert, K., \& Taerwe, L. (2005). Axial load behavior of largescale columns confined with fiber-reinforced polymer composites. ACI Structural Journal, 102(2), 258-267.

Mostofinejad, D., \& Ilia, E. (2014). Confining of square RC columns with FRP sheets using corner strip-batten technique. Construction and Building Materials, 70, 269-278. doi:10.1016/j.conbuildmat.2014.07.073

Mostofinejad, D., Moshiri, N., \& Mortazavi, N. (2015). Effect of corner radius and aspect ratio on compressive behavior of rectangular concrete columns confined with CFRP. Materials and Structures/Materiaux et Constructions, 48(1-2), 107-122. doi:10.1617/s11527-0130171-9

Oller, E., Cobo, D., \& Marí, A. R. (2011). Laminate debonding process of FRP-strengthened beams. Structure and Infrastructure Engineering, 7(1-2), 131-146. doi:10.1080/15732471003588569

Park, T. W., Na, U. J., Chung, L., \& Feng, M. Q. (2008). Compressive behavior of concrete cylinders confined by narrow strips of CFRP with spacing. Composites Part BEngineering, 39(7-8), 1093-1103. doi:10.1016/j.compositesb.2008.05.002

Pham, T. M., Doan, L. V., \& Hadi, M. N. S. (2013). Strengthening square reinforced concrete columns by circularisation and FRP confinement. Construction and Building Materials, 49, 490-499. doi:10.1016/j.conbuildmat.2013.08.082 
Pham, T. M., Hadi, M. N. S., \& Youssef, J. (2015). Optimized FRP Wrapping Schemes for Circular Concrete Columns under Axial Compression. Journal of Composites for Construction, 19(6), 04015015. doi:10.1061/(ASCE)CC.1943-5614.0000571

Priestley, M. J. N., Seible, F., Xiao, Y., \& Verma, R. (1994). Steel jacket retrofitting of reinforced concrete bridge columns for enhanced shear strength. Part 1: Theoretical considerations and test design. ACI Structural Journal, 91(4), 394-405.

Saljoughian, A., \& Mostofinejad, D. (2016a). Axial-flexural interaction in square RC columns confined by intermittent CFRP wraps. Composites Part B-Engineering, 89, 85-95. doi:10.1016/j.compositesb.2015.10.047

Saljoughian, A., \& Mostofinejad, D. (2016b). Corner Strip-Batten Technique for FRPConfinement of Square RC Columns under Eccentric Loading. Journal of Composites for Construction, 20(3), 04015077. doi:10.1061/(ASCE)CC.1943-5614.0000644

Sasmal, S., Khatri, C. P., \& Karusala, R. (2015). Numerical simulation of performance of nearsurface mounted FRP-upgraded beam-column sub-assemblages under cyclic loading. Structure and Infrastructure Engineering, 11(8), 1012-1027. doi:10.1080/15732479.2014.926376

Shannag, M. J., Al-Akhras, N. M., \& Mahdawi, S. F. (2014). Flexure strengthening of lightweight reinforced concrete beams using carbon fibre-reinforced polymers. Structure and Infrastructure Engineering, 10(5), 604-613. doi:10.1080/15732479.2012.757790

Tan, K. H. (2002). Strength enhancement of rectangular reinforced concrete columns using fiber-reinforced polymer. Journal of Composites for Construction, 6(3), 175-183. doi:10.1061/(ASCE)1090-0268(2002)6:3(175)

Tao, Z., Yu, Q., \& Zhong, Y. Z. (2008). Compressive behaviour of CFRP-confined rectangular concrete columns. Magazine of Concrete Research, 60(10), 735-745. doi:10.1680/macr.2007.00115

Teng, J. G., \& Lam, L. (2002). Compressive behavior of carbon fiber reinforced polymerconfined concrete in elliptical columns. Journal of Structural Engineering, 128(12), 15351543. doi:10.1061/(ASCE)0733-9445 
Teng, J. G., \& Lam, L. (2004). Behavior and modeling of fiber reinforced polymer-confined concrete. Journal of Structural Engineering, 130(11), 1713-1723. doi:10.1061/(ASCE)0733-9445(2004)130:11(1713)

Triantafyllou, G. G., Rousakis, T. C., \& Karabinis, A. I. (2015). Axially Loaded Reinforced Concrete Columns with a Square Section Partially Confined by Light GFRP Straps. Journal of Composites for Construction, 19(1), 04014035. doi:10.1061/(ASCE)CC.19435614.0000496

Wang, L. M., \& Wu, Y. F. (2008). Effect of corner radius on the performance of CFRPconfined square concrete columns: Test. Engineering Structures, 30(2), 493-505. doi:10.1016/j.engstruct.2007.04.016

Wu, Y., \& Zhou, Y. (2010). Unified Strength Model Based on Hoek-Brown Failure Criterion for Circular and Square Concrete Columns Confined by FRP. Journal of Composites for Construction, 14(2), 175-184. doi:10.1061/(ASCE)CC.1943-5614.0000062

Wu, Z., Zhang, D., \& Karbhari, V. M. (2010). Numerical simulation on seismic retrofitting performance of reinforced concrete columns strengthened with fibre reinforced polymer sheets. Structure and Infrastructure Engineering, 6(4), 481-496. doi:10.1080/15732470701801159

Yang, X., Wei, J., Nanni, A., \& Dharani, L. R. (2004). Shape Effect on the Performance of Carbon Fiber Reinforced Polymer Wraps. Journal of Composites for Construction, 8(5), 444-451. doi:10.1061/(ASCE)1090-0268(2004)8:5(444)

Youssf, O., Hassanli, R., \& Mills, J. E. (2017). Retrofitting square columns using FRP-confined crumb rubber concrete to improve confinement efficiency. Construction and Building Materials, 153, 146-156. doi:10.1016/j.conbuildmat.2017.07.108

Zeng, J. J., Guo, Y. C., Gao, W. Y., Li, J. Z., \& Xie, J. H. (2017). Behavior of partially and fully FRP-confined circularized square columns under axial compression. Construction and Building Materials, 152, 319-332. doi:10.1016/j.conbuildmat.2017.06.152

Zou, Y., \& Hong, H. P. (2011). Reliability assessment of FRP-confined concrete columns designed for buildings. Structure and Infrastructure Engineering, 7(3), 243-258. doi:10.1080/15732470802416998 
Table 1: Configuration of test specimens

\begin{tabular}{|c|c|c|c|c|c|c|c|}
\hline Group & Specimen & $\begin{array}{l}\text { Longitudinal } \\
\text { reinforcement }\end{array}$ & $\begin{array}{c}\text { Transverse } \\
\text { reinforcement }\end{array}$ & $\begin{array}{c}\text { Type of } \\
\text { wrapping }\end{array}$ & $\begin{array}{l}\text { Clear spacing of } \\
\text { CFRP strips (mm) }\end{array}$ & $\begin{array}{c}\text { Amount of CFRP } \\
\text { used* }\left(\mathrm{mm}^{2}\right)\end{array}$ & $\begin{array}{l}\text { Eccentricity } \\
(\mathrm{mm})\end{array}$ \\
\hline \multirow{4}{*}{$\mathrm{SN}$} & $\mathrm{SN}-0$ & \multirow{4}{*}{$4 \mathrm{~N} 12$} & \multirow{4}{*}{ R6@80 } & \multirow{4}{*}{ None } & \multirow{4}{*}{ - } & \multirow{4}{*}{0} & 0 \\
\hline & SN-15 & & & & & & 15 \\
\hline & $\mathrm{SN}-25$ & & & & & & 25 \\
\hline & $\mathrm{SN}-\mathrm{F}$ & & & & & & Flexural \\
\hline \multirow{4}{*}{ SI } & SI-0 & \multirow{4}{*}{ 4N12 } & \multirow{4}{*}{ R6@80 } & \multirow{4}{*}{$\begin{array}{c}\text { Intermittent } \\
\text { (width }=40 \mathrm{~mm} \text { ) }\end{array}$} & \multirow{4}{*}{40} & \multirow{4}{*}{862,560} & 0 \\
\hline & SI-15 & & & & & & 15 \\
\hline & SI-25 & & & & & & 25 \\
\hline & SI-F & & & & & & Flexural \\
\hline \multirow{4}{*}{ CI } & CI-0 & \multirow{4}{*}{$4 \mathrm{~N} 12$} & \multirow{4}{*}{ R6@80 } & \multirow{4}{*}{$\begin{array}{c}\text { Intermittent } \\
(\text { width }=50 \mathrm{~mm})\end{array}$} & \multirow{4}{*}{50} & \multirow{4}{*}{$1,049,650$} & 0 \\
\hline & CI-15 & & & & & & 15 \\
\hline & CI-25 & & & & & & 25 \\
\hline & CI-F & & & & & & Flexural \\
\hline
\end{tabular}

* Amount of CFRP used per specimen = (length) $\mathrm{x}($ width $) \mathrm{x}($ number of layers $)$ 
Table 2: Experimental results of the concentrically and eccentrically loaded specimens

\begin{tabular}{|c|c|c|c|c|c|c|c|c|}
\hline Specimen & Eccentricity & $\begin{array}{l}\text { Yield axial load, } \\
\qquad P_{y}(\mathrm{kN})\end{array}$ & $\begin{array}{c}\text { Axial } \\
\text { deformation } \\
\text { at } P_{y}(\mathrm{~mm})\end{array}$ & $\begin{array}{l}\text { Ultimate axial } \\
\text { load, } P_{\text {ult }}(\mathrm{kN})\end{array}$ & $\begin{array}{c}\text { Axial } \\
\text { deformation } \\
\text { at } P_{u l t}(\mathrm{~mm})\end{array}$ & $\begin{array}{c}\text { Lateral } \\
\text { deformation } \\
\text { at } P_{\text {ult }}(\mathrm{mm})\end{array}$ & $\begin{array}{c}\text { Ultimate } \\
\text { deformation } \\
(\mathrm{mm})\end{array}$ & $\begin{array}{c}\text { Ductility } \\
\lambda\end{array}$ \\
\hline $\mathrm{SN}-0$ & & 902.0 & 2.2 & 993.5 & 2.8 & - & 3.2 & 1.5 \\
\hline SI-0 & 0 & 987.0 & 2.5 & 1204.4 & 14.9 & - & 17.0 & 6.8 \\
\hline CI-0 & & 1535.6 & 2.4 & 2268.5 & 11.2 & - & 12.2 & 5.1 \\
\hline SN-15 & & 687.0 & 1.9 & 731.8 & 2.2 & 2.5 & 2.4 & 1.3 \\
\hline SI-15 & 15 & 836.0 & 2.2 & 905.1 & 2.9 & 3.6 & 5.1 & 2.3 \\
\hline CI-15 & & 1432.1 & 2.6 & 1667.9 & 6.2 & 8.8 & 8.0 & 3.1 \\
\hline $\mathrm{SN}-25$ & & 595.4 & 1.9 & 630.2 & 2.2 & 2.5 & 2.5 & 1.3 \\
\hline SI-25 & 25 & 684.0 & 2.3 & 742.8 & 3.1 & 4.7 & 6.0 & 2.6 \\
\hline CI-25 & & 1303.2 & 2.9 & 1487.5 & 5.09 & 8.8 & 16.1 & 5.6 \\
\hline
\end{tabular}


Table 3: Experimental results of the specimens tested under four-point flexural load

\begin{tabular}{ccccccc}
\hline Specimen & $\begin{array}{c}\text { Yield load, } \\
P_{y}(\mathrm{kN})\end{array}$ & $\begin{array}{c}\text { Midspan } \\
\text { deflection } \\
\text { at } P_{y}(\mathrm{~mm})\end{array}$ & $\begin{array}{c}\text { Ultimate } \\
\text { load, } P_{\text {ult }} \\
(\mathrm{kN})\end{array}$ & $\begin{array}{c}\text { Midspan } \\
\text { deflection } \\
\text { at } P_{\text {ult }}(\mathrm{mm})\end{array}$ & $\begin{array}{c}\text { Ultimate } \\
\text { deflection } \\
(\mathrm{mm})\end{array}$ & $\begin{array}{c}\text { Ductility } \\
\lambda\end{array}$ \\
\hline SN-F & 111.1 & 3.5 & 126.1 & 6.11 & 56.4 & 16.1 \\
SI-F & 126.0 & 4.1 & 160.4 & 32.7 & 41.4 & 10.1 \\
CI-F & 147.7 & 2.9 & 218.1 & 27.9 & 37.0 & 12.8 \\
\hline
\end{tabular}


Table 4: Experimental axial load and bending moment interactions of the test specimens

\begin{tabular}{ccccc}
\hline \multirow{2}{*}{ Group } & Specimen & $\begin{array}{c}\text { Ultimate load } \\
(\mathrm{kN})\end{array}$ & $\begin{array}{c}\text { Lateral deformation at } \\
\text { ultimate axial load }(\mathrm{mm})\end{array}$ & $\begin{array}{c}\text { Maximum bending moment } \\
(\mathrm{kN} . \mathrm{m})\end{array}$ \\
\hline \multirow{3}{*}{ SN } & SN-0 & 993.5 & 0 & 0 \\
& SN-15 & 731.8 & 2.5 & 12.8 \\
& SN-25 & 630.2 & 2.5 & 17.3 \\
& SN-F & 126.1 & 6.1 & 14.7 \\
\hline \multirow{3}{*}{ SI } & SI-0 & 1204.4 & 0 & 0 \\
& SI-15 & 905.1 & 3.6 & 16.8 \\
& SI-25 & 742.8 & 4.7 & 22.1 \\
& SI-F & 160.4 & 32.7 & 18.7 \\
\hline \multirow{2}{*}{ CI } & CI-0 & 2268.5 & 0 & 39.7 \\
& CI-15 & 1667.9 & 8.8 & 44.8 \\
& CI-25 & 1487.5 & 8.8 & 25.4 \\
\hline
\end{tabular}



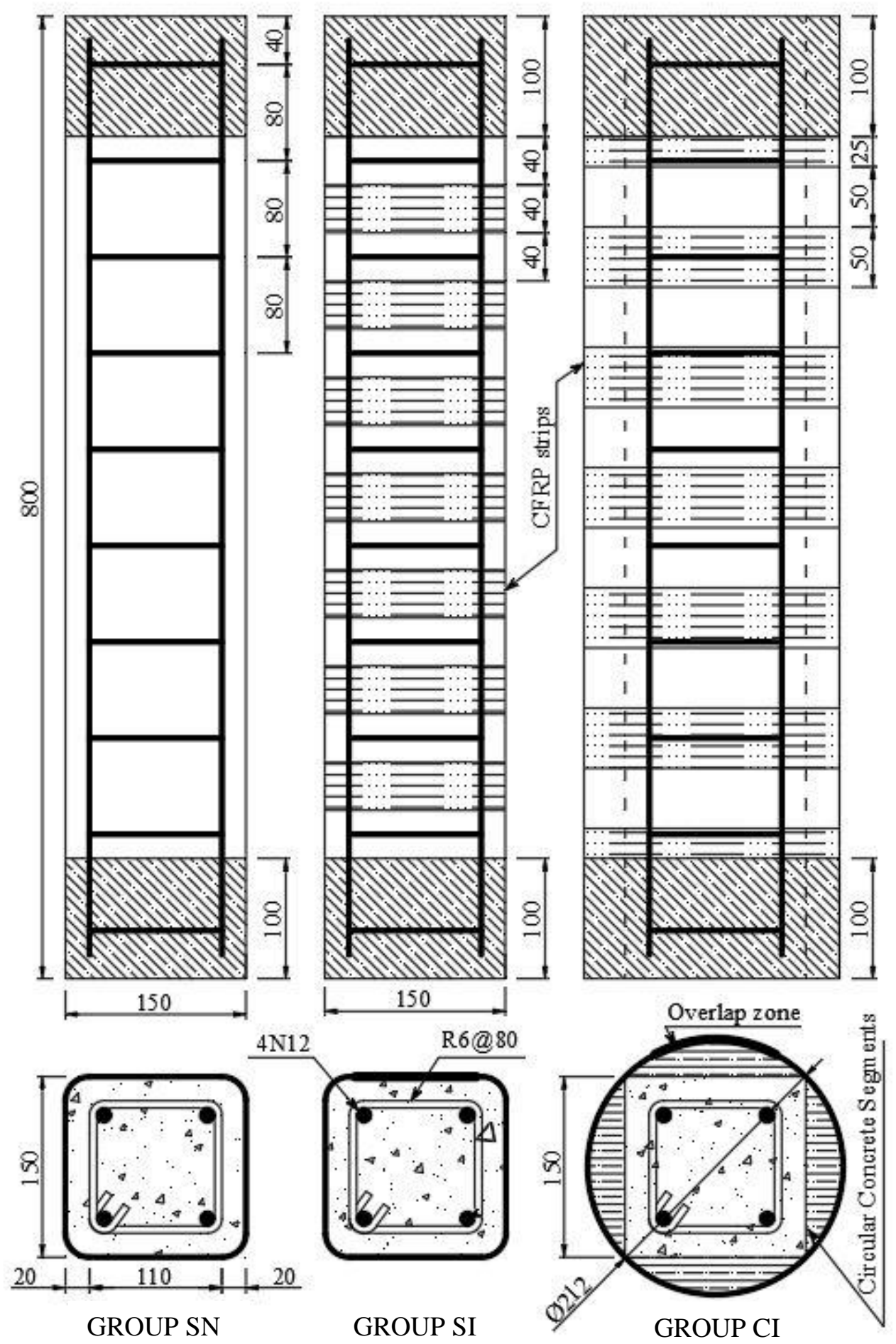

Figure 1: Details of the test specimens (All dimensions are in $\mathrm{mm}$ ) 


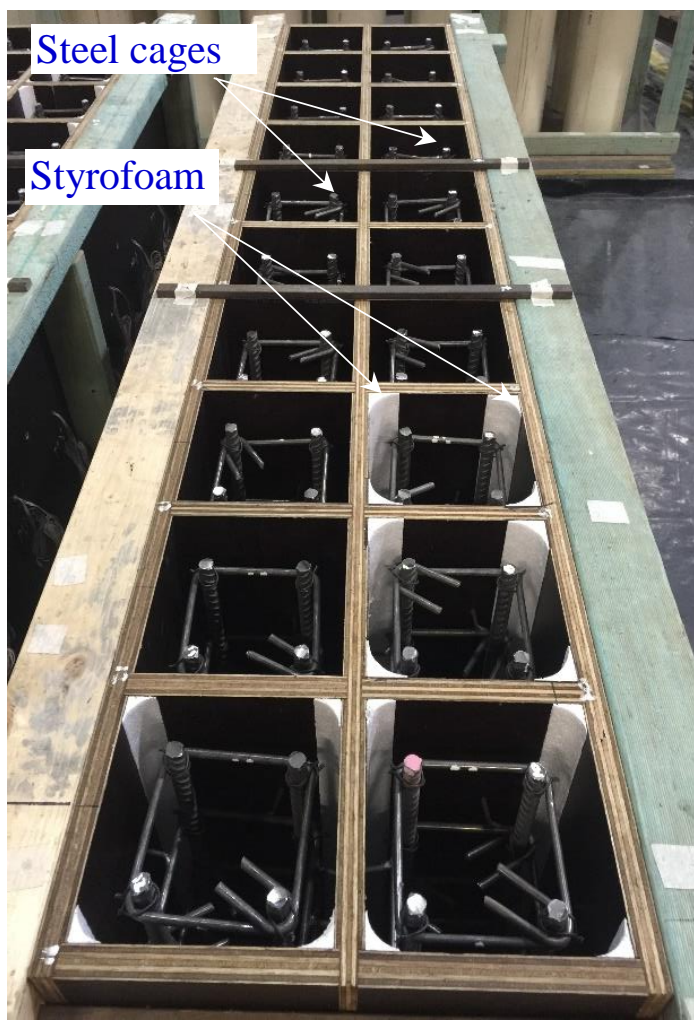

(a)

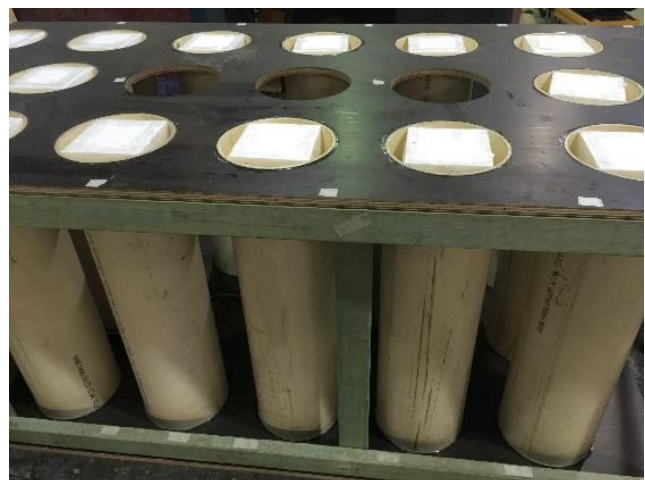

(b)

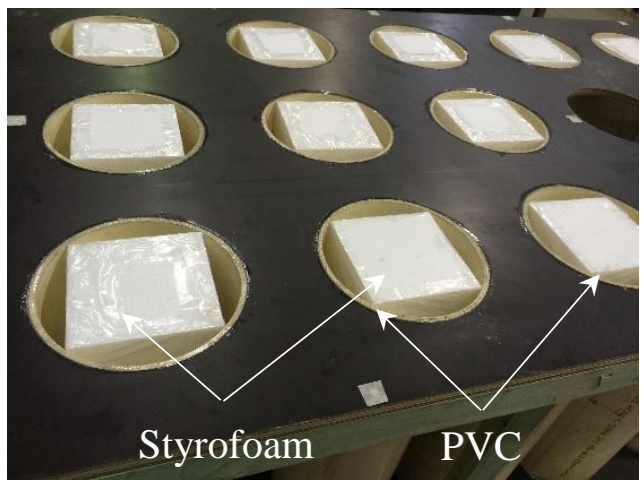

(c)

Figure 2: Details of formworks: (a) formwork of square RC specimens, (b) formwork of concrete segments and (c) top view of the formwork of concrete segments 


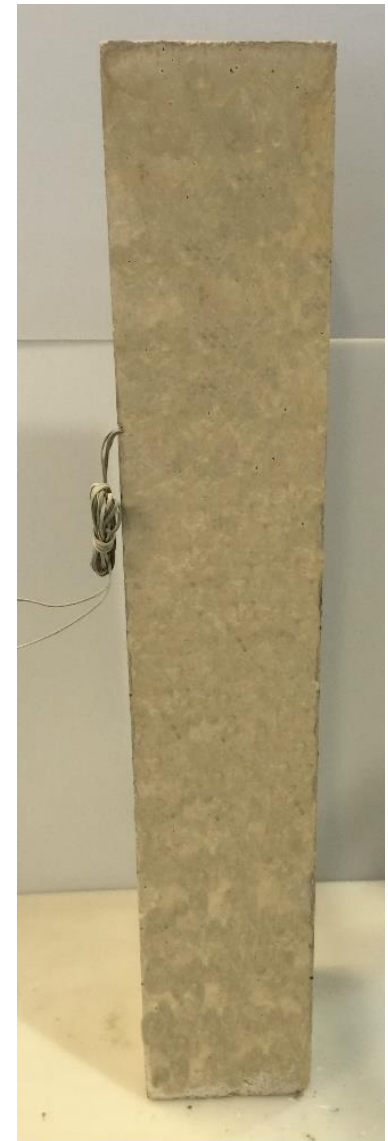

(a)

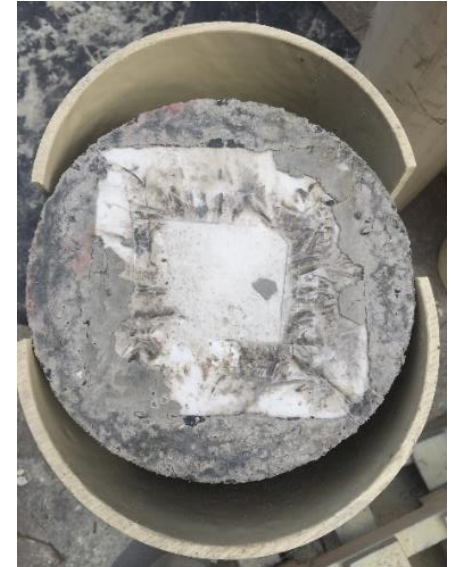

(b)

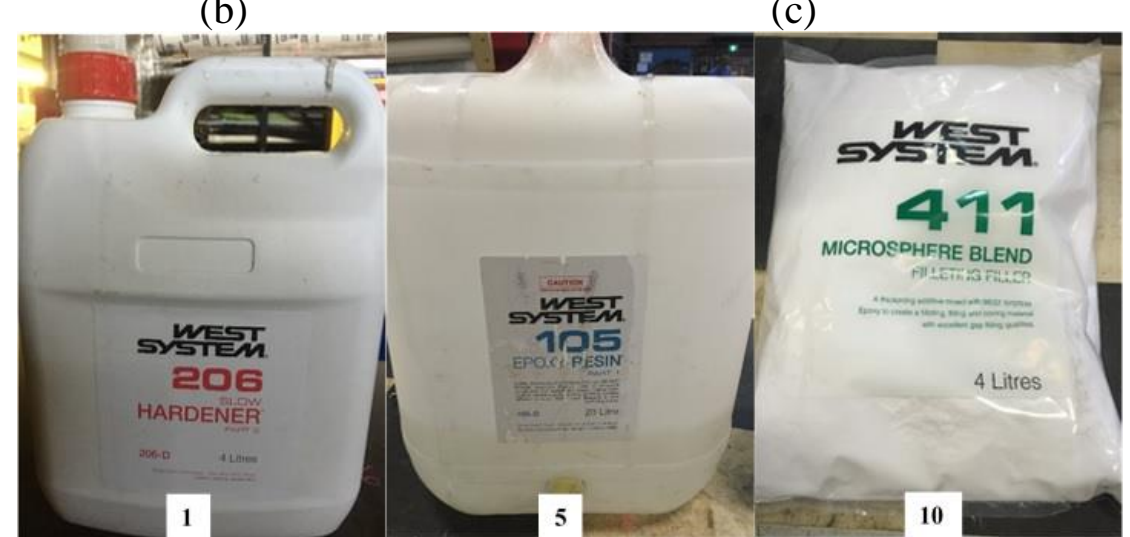

(d)

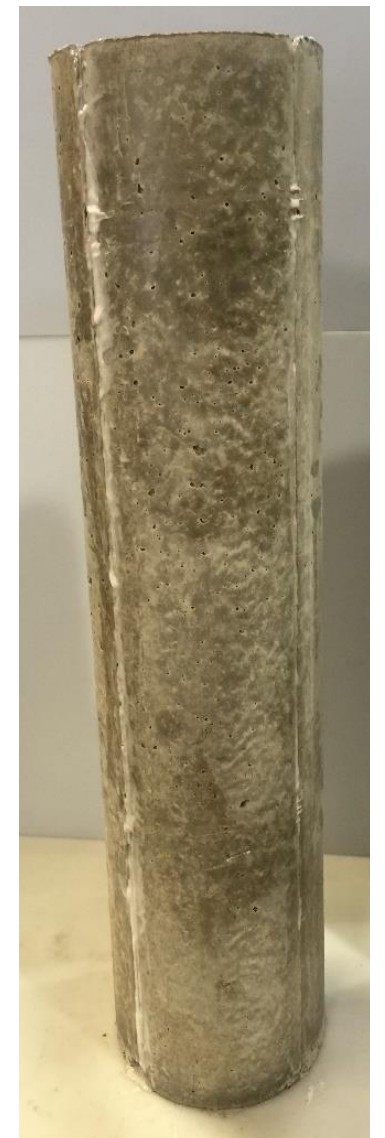

(e)

Figure 3: The bonding process of circularized square RC specimens: (a) square RC specimen, (b) concrete segments in formwork, (c) concrete segments, (d) materials used as concrete bonding agent and (e) circularized square RC specimen 


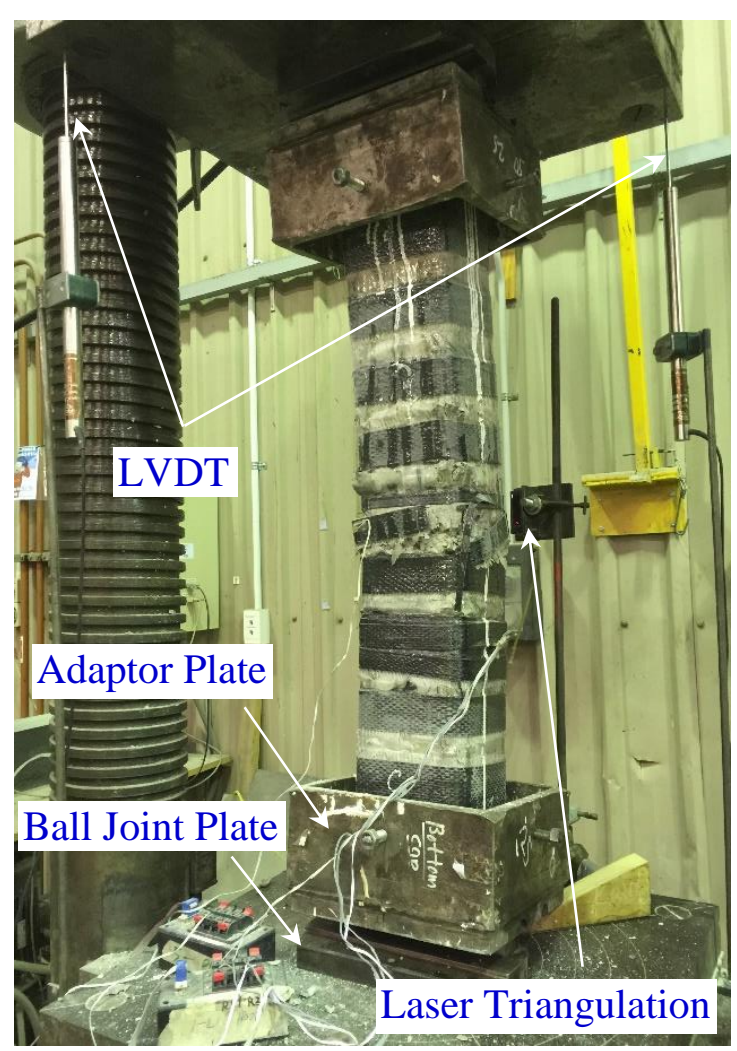

(a)

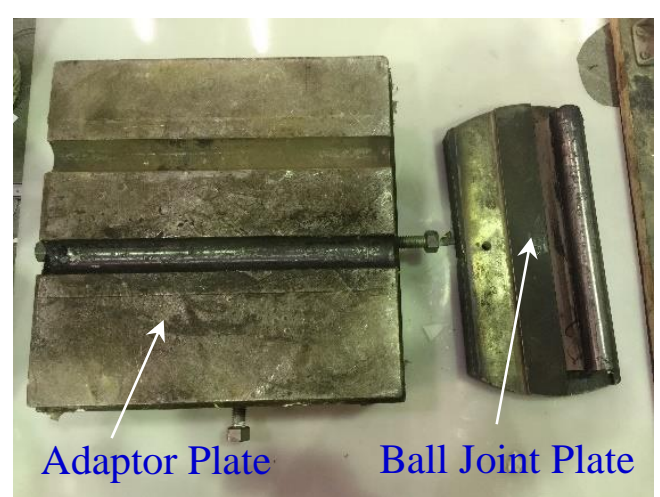

(b)

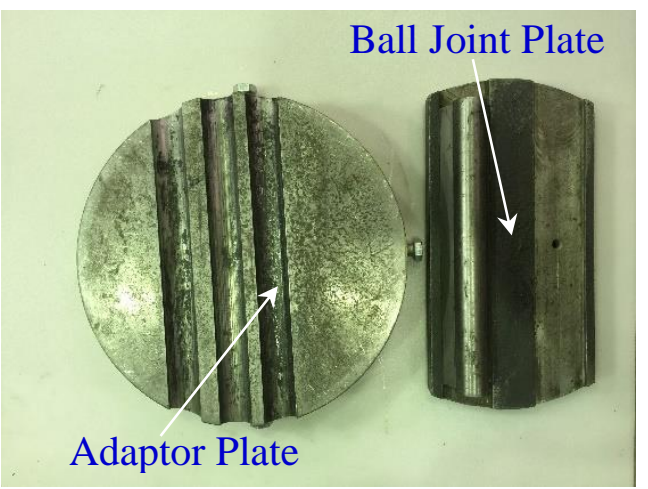

(c)

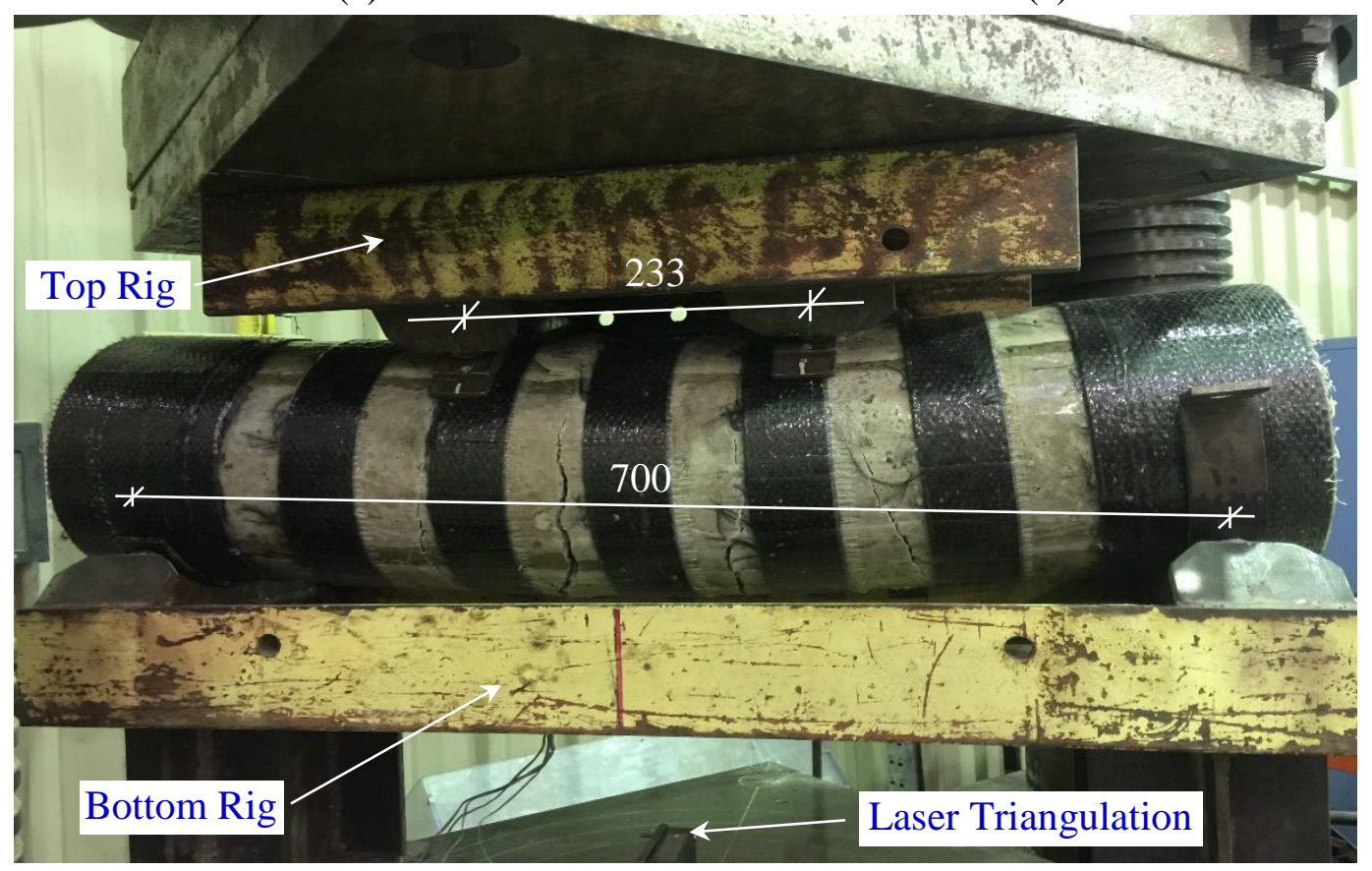

(d)

Figure 4: Test setup: (a) test setup of the column specimens, (b) loading head of square column specimens, (c) loading head of circular column specimens and (d) test setup of the beam specimens 


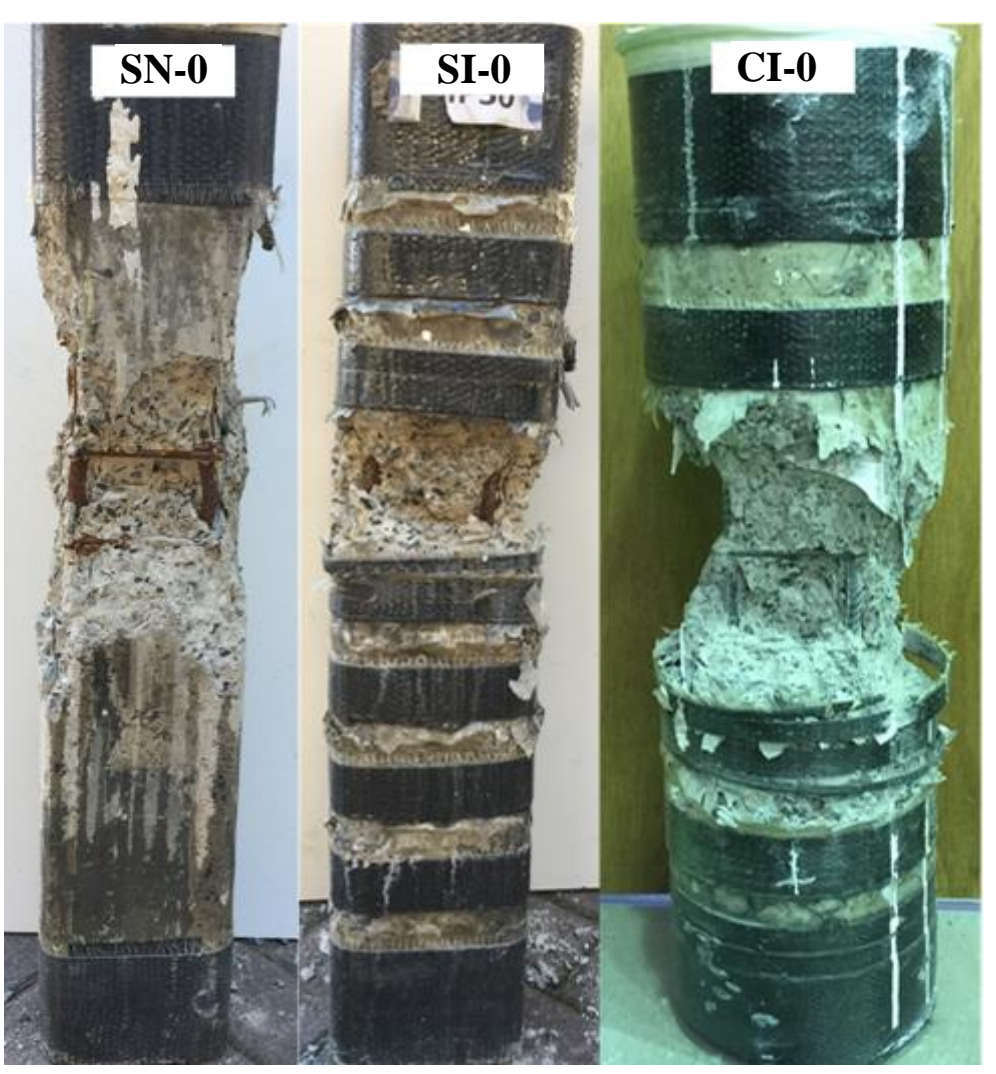

(a)
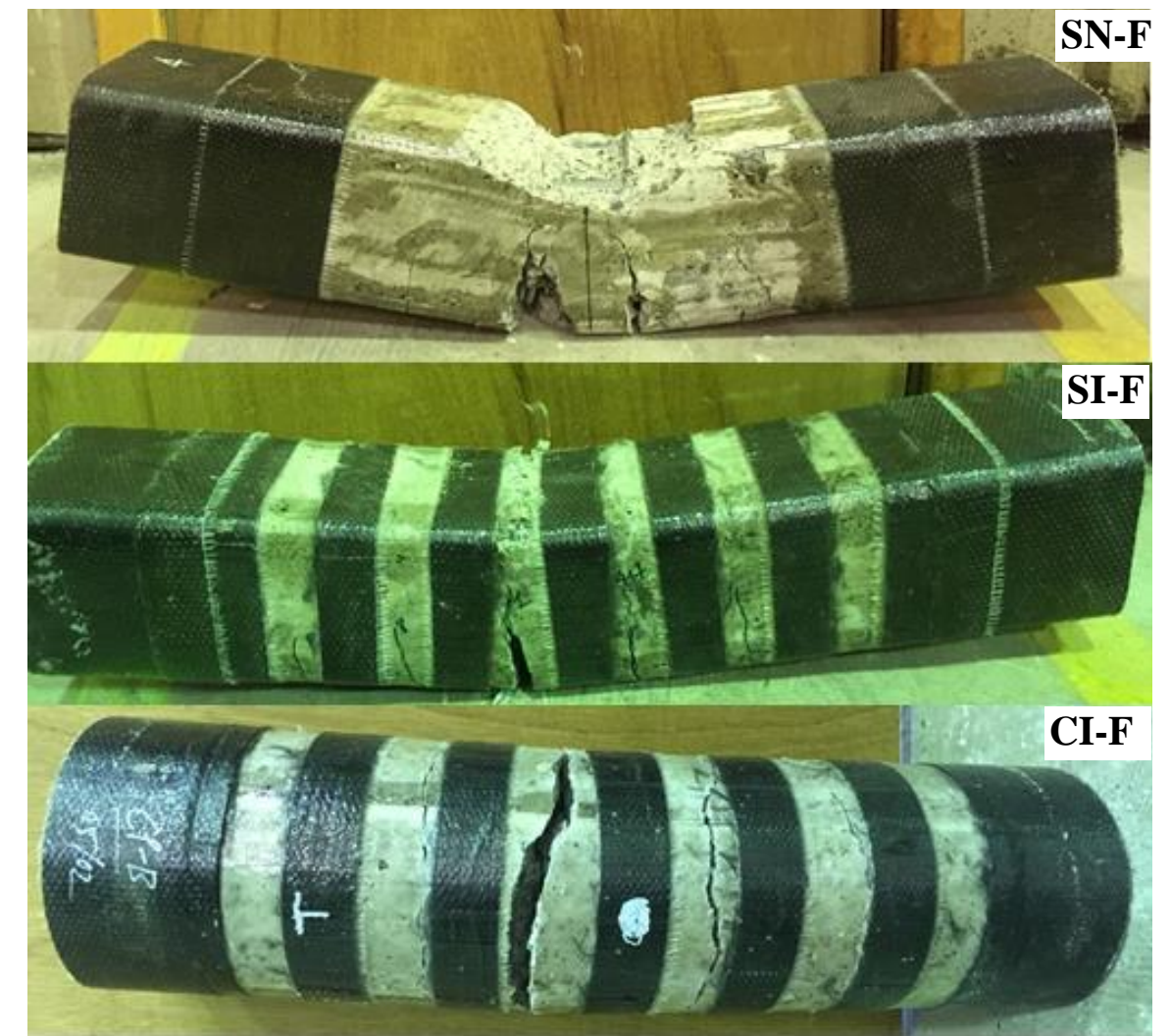

(b)

Figure 5: Failure modes of specimens: (a) Specimens tested under concentric axial load and (b) specimens tested under four-point flexural load 


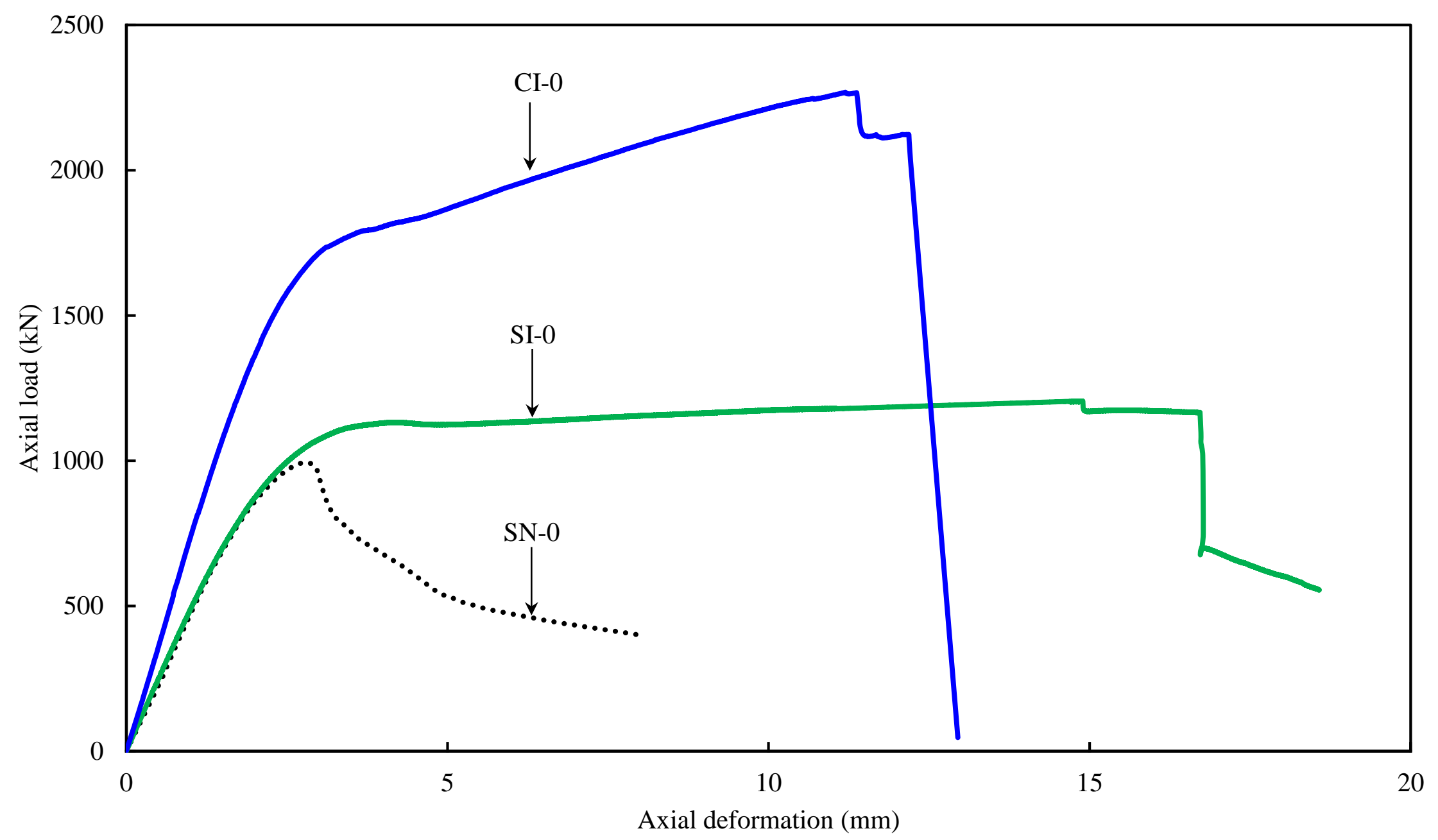

Figure 6: Axial load-axial deformation responses of the specimens tested under concentric axial load 


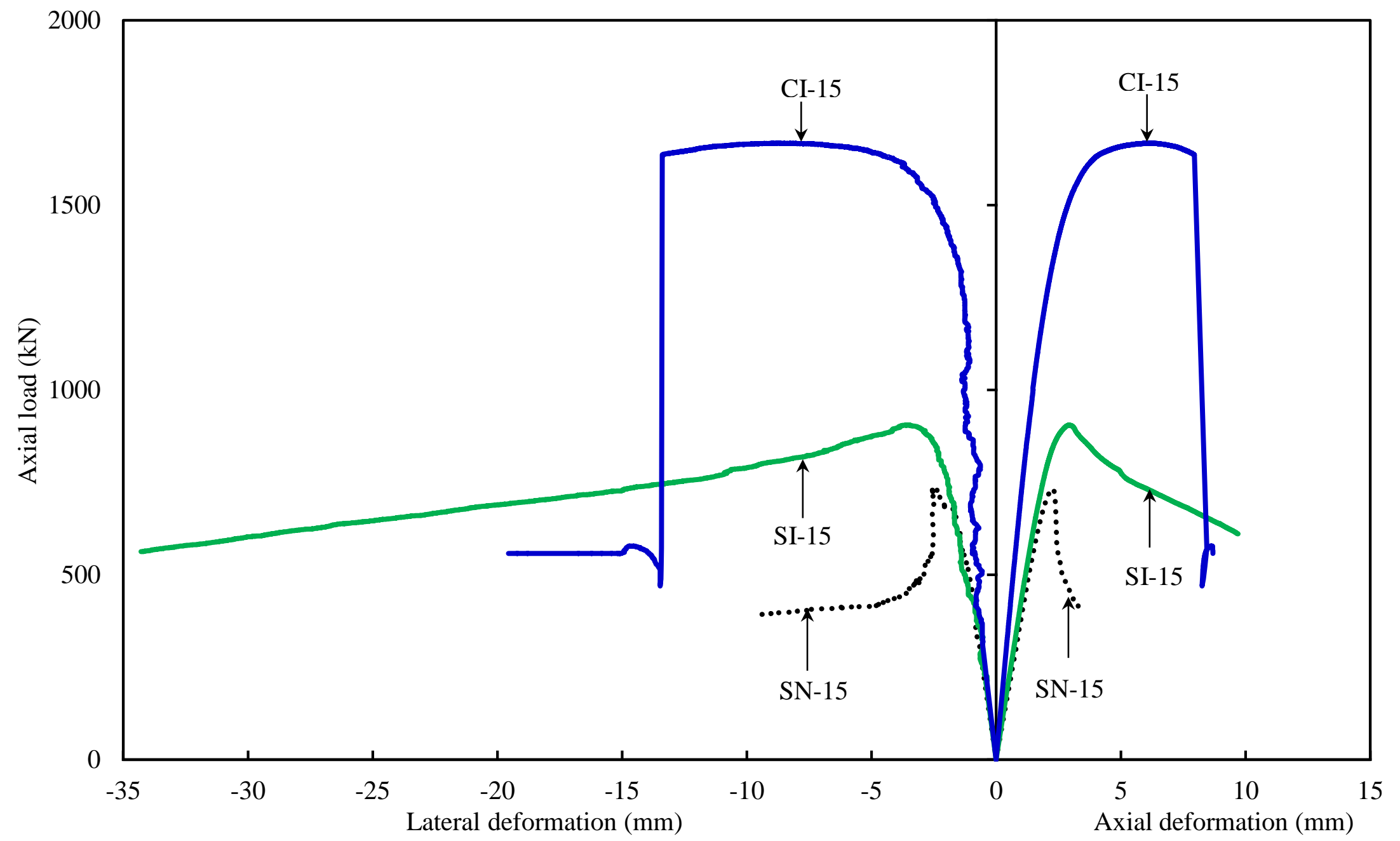

Figure 7: Axial load-axial deformation and axial load-lateral deformation responses of specimens tested under $15 \mathrm{~mm}$ eccentric axial load 


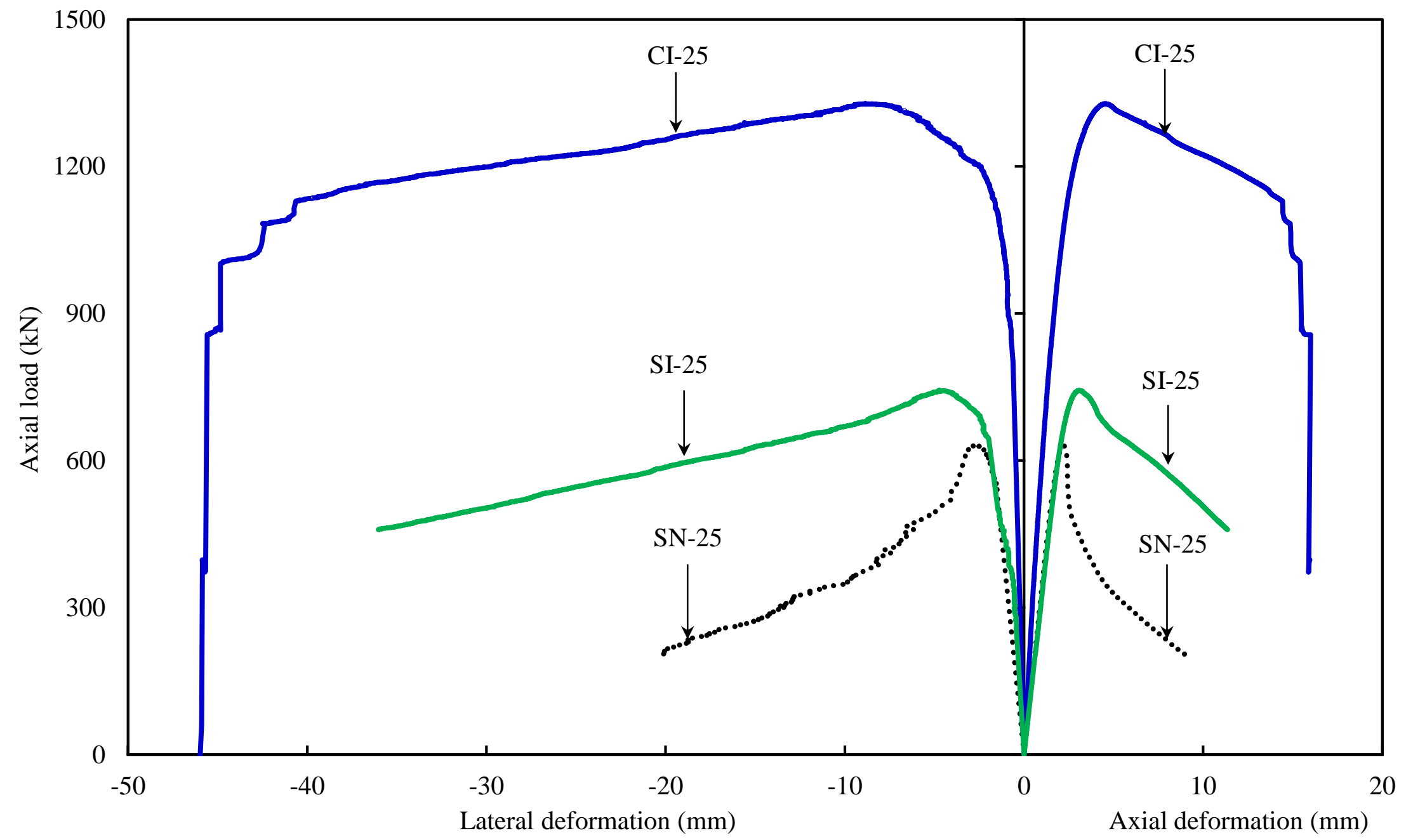

Figure 8: Axial load-axial deformation and axial load-lateral deformation responses of specimens tested under $25 \mathrm{~mm}$ eccentric axial load 


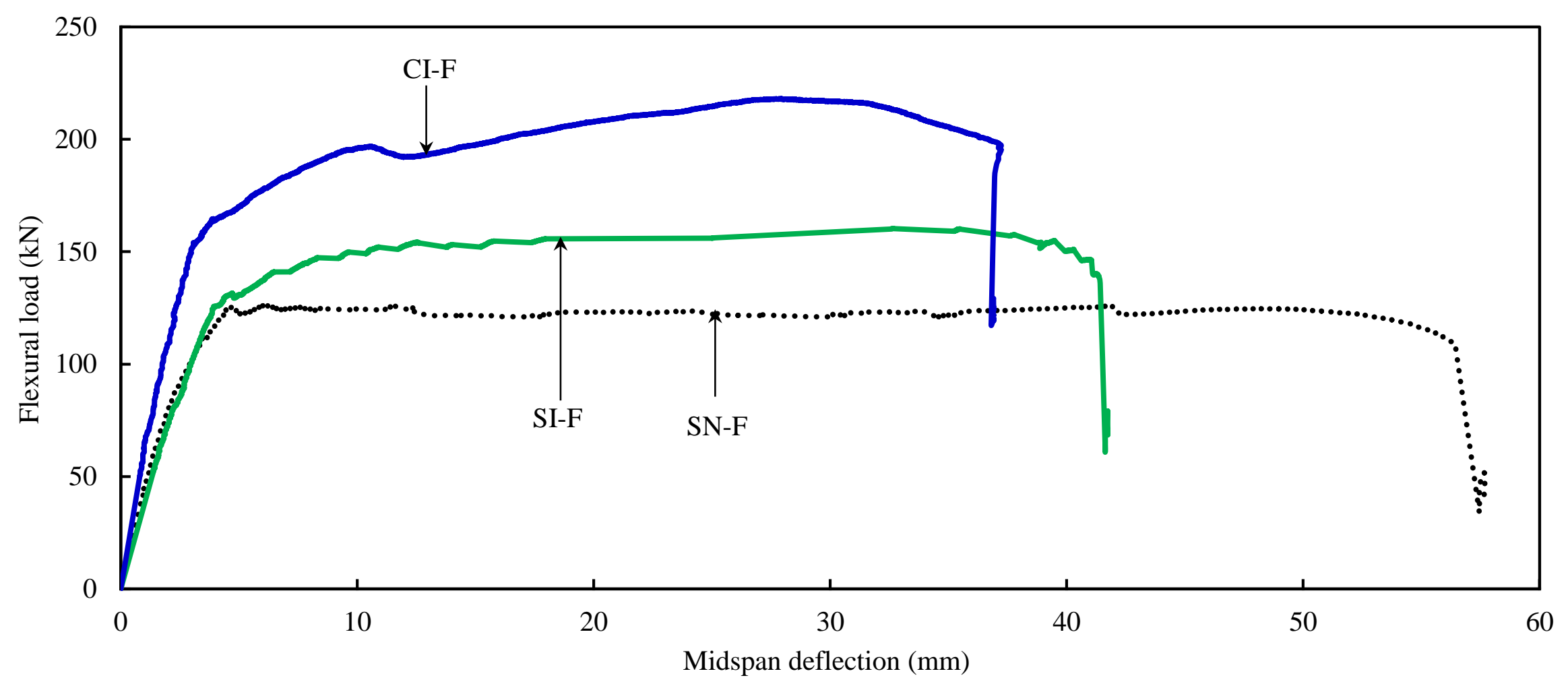

Figure 9: Flexural load-midspan deflection responses of specimens tested under four-point flexural load 


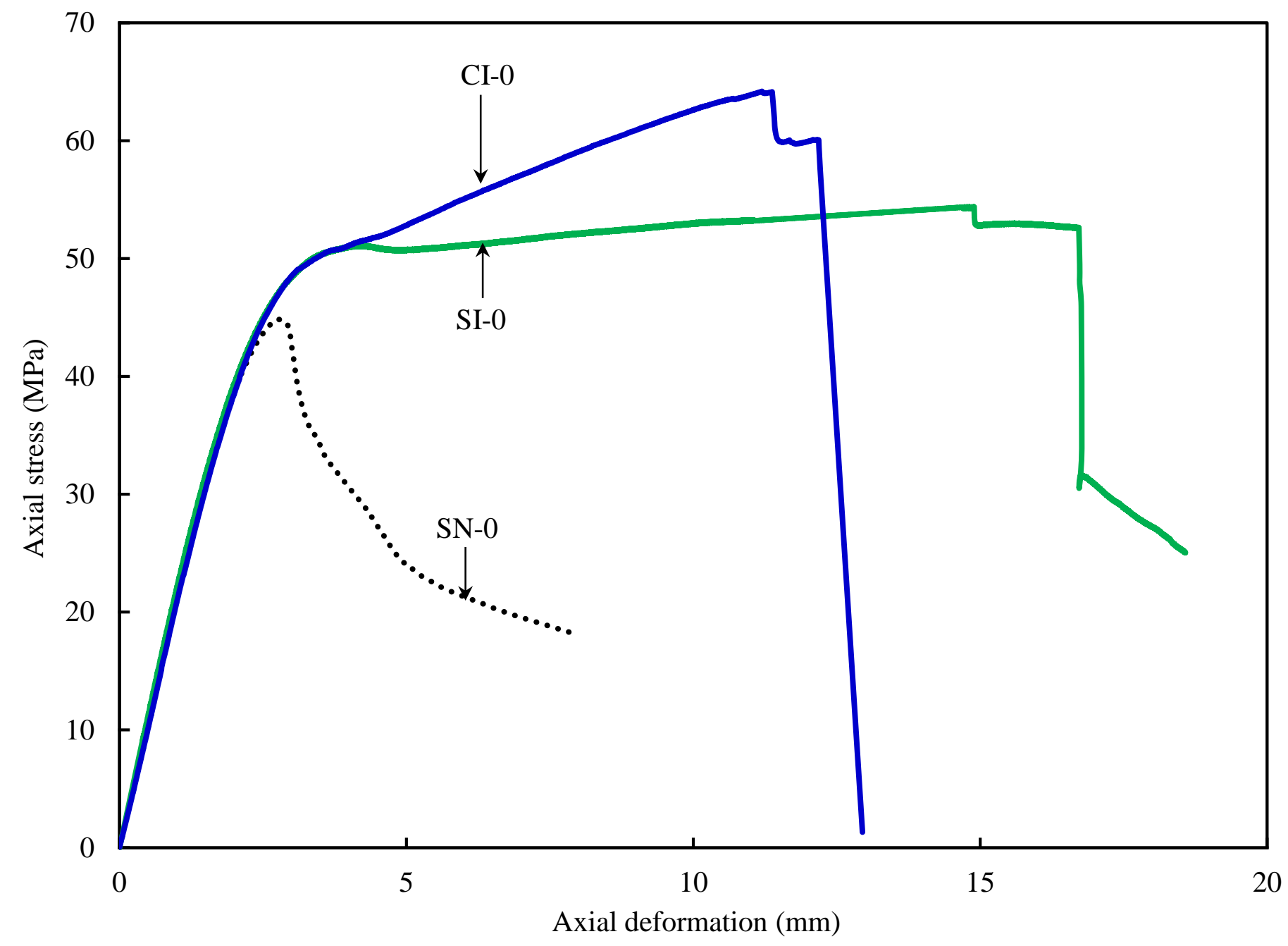

Figure 10: Axial stress-axial deformation responses of specimens tested under concentric axial load 


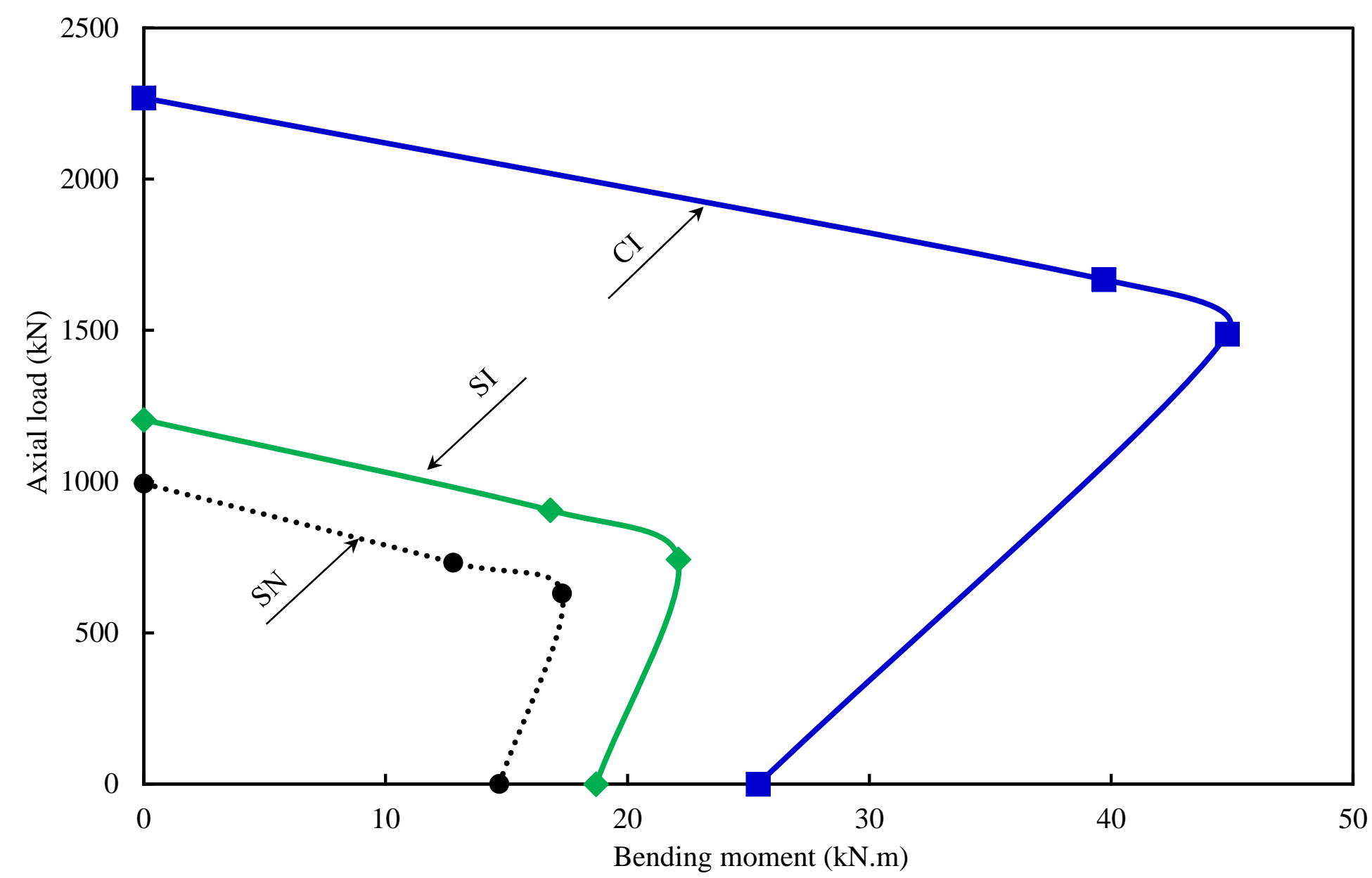

Figure 11: Experimental axial load-bending moment interaction diagrams 